\title{
Simulating the dynamics of primary productivity of a Sonoran ecosystem: Model parameterization and validation
}

\author{
Weijun Shen ${ }^{\mathrm{a}, \mathrm{b}}$, Jianguo $\mathrm{Wu}^{\mathrm{a}, *}$, Paul R. Kemp ${ }^{\mathrm{c}}$, \\ James F. Reynolds ${ }^{d}$, Nancy B. Grimm ${ }^{\mathrm{a}}$ \\ ${ }^{a}$ Faculty of Ecology, Evolution and Environmental Sciences, School of Life Sciences, \\ Arizona State University, P.O. Box 874501, Tempe, AZ 85287-4501, USA \\ b South China Botanical Garden, Chinese Academy of Sciences, Guangzhou 510650, PR China \\ c Biology Department, University of San Diego, 5998 Alcala Pk., San Diego, CA 92110, USA \\ ${ }^{\mathrm{d}}$ Department of Botany and Nicholas School of the Environment and Earth Science, Duke University, Durham, NC 27708-0340, USA
}

Received 17 September 2004; received in revised form 30 March 2005; accepted 1 April 2005

Available online 13 June 2005

\begin{abstract}
Modeling has played a crucial role in understanding the structural and functional dynamics of forest and grassland ecosystems in the past decades, but relatively few ecosystem models have been developed for deserts. Adapting an existing desert ecosystem model to new regions with different community components and environmental settings may testify to the generality of model applicability, further verify model structure and formulations, and provide new insight into understanding desert ecosystem functioning. In this paper, we use a desert ecosystem model that was originally developed for the Chihuahuan Desert, Patch Arid Land Simulator-Functional Types (PALS-FT), to estimate the aboveground annual net primary productivity (ANPP) of a creosotebush (Larrea tridentata)-dominated Sonoran Desert ecosystem in the Phoenix metropolitan area, home to the Central Arizona-Phoenix Long-Term Ecological Research Project (CAP LTER). We modified and parameterized the model using meteorological data, ecophysiological parameters for different plant functional types, and site characteristic data from the CAP LTER study area and an independent test site in the San Simon Valley of southeastern Arizona. Model predictions were validated and calibrated using field observations from the San Simon Valley test site. The results showed that PALS-FT was able to simulate ANPP of this typical Sonoran Desert ecosystem reasonably well, with a relative error of $\pm 2.4 \%$ at the ecosystem level and generally less than $\pm 25 \%$ at the functional-type level. We then used the model to simulate ANPP and its seasonal and inter-annual dynamics for a similar ecosystem in the CAP LTER study area. The model predicted average annual ANPP of $72.3 \mathrm{~g} \mathrm{~m}^{-2} \mathrm{y}^{-1}$, ranging from $11.3 \mathrm{~g} \mathrm{~m}^{-2} \mathrm{y}^{-1}$ to $229.6 \mathrm{~g} \mathrm{~m}^{-2} \mathrm{y}^{-1}$ in a 15 -year simulation. The simulated average ANPP of the Sonoran Desert ecosystem is close to field observations in other areas of the Sonoran Desert, and the range of variation also is close to that reported by other researchers for arid and semiarid ecosystems. The dynamics of ecosystem ANPP in response to fluctuations in
\end{abstract}

\footnotetext{
* Corresponding author. Tel.: +1 480965 1063; fax: +1 4809656899 .

E-mail address: jingle.wu@asu.edu (J.Wu).
} 
annual precipitation simulated by the model agreed well with the known relationship between ANPP and precipitation in arid and semiarid systems. A closer examination of this relationship at the level of plant functional types further revealed that seasonal distribution of rainfall significantly affected ANPP. A comparison between the PALS-FT model prediction and two regression models for North American warm deserts showed that both regression models underestimated the Larrea ecosystem ANPP, while the process-based PALS-FT model provided the most accurate prediction among the three models. This study provides a validation for use of the PALS-FT model to investigate Sonoran desert ecosystem responses to environmental changes.

Published by Elsevier B.V.

Keywords: Net primary productivity; Sonoran Desert; Larrea; PALS-FT; Model parameterization; Model validation; Long-term ecological research

\section{Introduction}

Arid and semiarid regions occupy over one third of the world's land surface and are home to more than $20 \%$ of the global human population (Reynolds and Smith, 2002). Many drylands have been degraded by overcultivation, overgrazing, fuel gathering, urbanization, and climate change (Schlesinger et al., 1990; Wu, 2001; Reynolds and Smith, 2002). With the accelerating rate of desertification around the world, especially in Africa and central Asia, the capacity of arid lands to support humans, livestock, and wild animals is decreasing substantially. Understanding the basic functioning of desert ecosystems is thus of paramount importance to combating desertification and supporting sustainable use of arid land. An important indicator of ecosystem functioning is aboveground net primary productivity. It not only reflects how well the primary producers of an ecosystem are growing, but also indicates the amount of energy available to consumers and decomposers that, in turn, drive other important ecosystem processes (e.g. biogeochemical cycles, decomposition). The primary production of desert ecosystems has been a major research topic for decades (Noy-Meir, 1973; Fischer and Turner, 1978; Hadley and Szarek, 1981; Ludwig, 1987; Whitford, 2002). Studies have investigated water-use efficiency (Webb et al., 1978; LeHouerou et al., 1988), below-ground productivity (Caldwell and Camp, 1974; Bell et al., 1979), relationships between productivity and rainfall variability (Ludwig, 1986; LeHouerou et al., 1988), and productivity of individual species or functional groups (Chew and Chew, 1965; Burk and Dick-Peddie, 1973; Whittaker and Niering, 1975; Johnson et al., 1978; Reynolds et al., 1980, 1997; Fisher et al., 1988; Turner and Randall, 1989). While these studies, based on field observations and measurements, provide valuable insight into desert ecosystem processes, the generally short duration of the studies often limits the ability to obtain a clear understanding of cause and effect relationship that govern productivity in these highly temporally variable ecosystems. Thus, ecosystem simulation is a potentially powerful tool to aid in the understanding of ecosystem functioning, especially with respect to temporal processes such as climate variability and atmospheric change (e.g. changes in precipitation patterns, $\mathrm{CO}_{2}, \mathrm{~N}$ deposition), as well as other human perturbations and management activities. However, model development with respect to desert ecosystems has lagged behind that compared with some other ecosystems, e.g. forest and grasslands (see Tiktak and van Grinsven, 1995; Ryan et al., 1996; Parton et al., 1996).

Models for estimating terrestrial ANPP can be categorized into three types: statistical models, parametric models, and process models (Reynolds et al., 1993; Ruimy et al., 1994), in which processbased models are generally considered to be more useful for understanding the mechanisms of plant growth and plant-environment interactions, and for extrapolating predictions of ecosystem responses to environmental changes. Most ecosystem models for desert ecosystems are either statistical (e.g. Noy-Meir, 1973; Webb et al., 1978; LeHouerou et al., 1988) or process models (e.g. Reynolds et al., 1980, 1997; Reynolds and Cunningham, 1981). The Patch Arid Land Simulator-Functional Types (PALS-FT) is a mechanistic process-based model developed originally for the Chihuahuan Desert ecosystem in the Jornada Basin, New Mexico, USA (Reynolds et al., 1997). It has been used to study effects of disturbances on grassland-shrubland transition (Gao and Reynolds, 2003), effects of rainfall variability on canopy transpiration and soil water dynamics (Reynolds et al., 2000), and ecosystem responses to climate change in the 
Chihuanhuan Desert (Reynolds et al., 1997). Applying the model and expanding these studies to new regions, longer time frames, and/or new types of environmental changes (e.g. urbanization-induced environmental changes) can further verify the structural rationality and predictive accuracy of the model and provide new insight into desert ecosystem functioning.

As part of the effort to understand and predict how urbanization affects ecosystem processes in metropoli$\tan$ Phoenix, Arizona, USA, a city in the Sonoran Desert (see Grimm et al., 2000), the main objective of this study was to adapt and evaluate the PALS-FT model for the Sonoran desert, which boasts the highest plant diversity among the four North American Deserts (Sonoran, Chihuahuan, Mojave, and the Great Basin). This is due in part to the presence of both summer and winter showers in the Sonoran Desert compared to predominately summer rainfall in the Chihuanhuan Desert and winter rainfall in the Great Basin and Mojave Deserts (Brown, 1994; MacMahon, 2000). Specifically, we sought to determine whether the PALS-FT model can be applied to simulate the ecosystem ANPP of the Larrea dominated Sonoran Desert ecosystem with acceptable accuracy and consistency against field observations. We first briefly describe the structure and formulations of the PALS-FT model including modifications for application to the Sonoran Desert. The model parameter development and evaluation was accomplished using data from an independent testing site in the southeastern Sonoran Desert. The model was then used to examine seasonal and inter-annual patterns of ANPP in response to precipitation fluctuations over the northwest CAP study area of the Sonoran Desert. The PALS-FT model predictions were also compared with those of regression models that had been developed for the North American hot deserts, and the potential uses of the model to investigate urbanization effects on desert ecosystem function are discussed.

\section{Model description}

PALS-FT is a physiologically based ecosystem model that simulates the dynamics of carbon $(\mathrm{C})$, nitrogen $(\mathrm{N})$, and water $\left(\mathrm{H}_{2} \mathrm{O}\right)$ cycling of a desert ecosystem in a daily time step, with explicit consideration of plant functional types (FTs) of shrub, subshrub, perennial grasses, forbs, C3 winter-annual, and C4 summer-annual species (Reynolds and Cunningham, 1981; Reynolds et al., 1993, 1997, 2000; Kemp et al., 1997). The model was developed based on the hypothesis that changes in ecosystem structure and function are determined primarily by the dynamics of different plant FTs and soil resource distributions (Reynolds et al., 1997). PALS-FT consists of four interacting modules: (i) atmospheric driving variables and surface energy budget, (ii) soil water distribution and water cycling, (iii) production of plant FTs, and (iv) nutrient $(\mathrm{C}, \mathrm{N})$ cycling. PALS-FT is similar to patch-dynamic models (e.g. Shugart, 1984; Wu and Levin, 1994, 1997) in that it simulates ecological processes on a "patch" of certain size. The patch size used for PALS is variable, depending upon the desired resolution, FT composition, and interaction among adjacent patches. Previous studies using PALS-FT considered relatively small patch sizes (ca. 1-30 $\mathrm{m}^{2}$ ) in order to investigate small-scale spatial heterogeneity along a topographic gradient (Reynolds et al., 1997, 2004; Gao and Reynolds, 2003). But in this study, we treated the "patch" as a generalized ecosystem unit at the scale of $1-100 \mathrm{~km}^{2}$ for the purpose of representing a geographic area with relatively homogeneous abiotic conditions and similar ecosystem components. Model inputs and initialization includes data on climatic conditions, soil physical properties, plant and soil C and $\mathrm{N}$ storage, and plant ecophysiological parameters. Major model output variables include ANPP, soil evaporation, canopy transpiration, vegetation cover, soil organic matter, and soil $\mathrm{C}$ and $\mathrm{N}$ mineralization. Because PALS-FT has already been described in previous studies (Reynolds et al., 1997, 2000, 2004), we provide only an overview of the general model, focusing on the elements that were modified or are particularly relevant to the objectives of our study.

\subsection{Atmospheric driving variables and surface energy budget}

This module includes inputs of environmental driving variables (e.g. daily precipitation, maximum and minimum temperatures, solar radiation, relative humidity, ambient $\mathrm{CO}_{2}$ concentration, and $\mathrm{N}$ deposition rate) and the calculation of other environmental variables using these input driving variables (e.g. day length or photoperiod, mean air temperatures, soil temperature, and vapor pressure deficit (VPD). 
Photoperiod is calculated as a cosine function of Julian day:

Photoperiod

$$
=12+2 \cos \left(\pi \times\left(\frac{\text { Julian day }-172}{182.5}\right)\right)
$$

VPD, an important variable in determining stomatal conductance, is the difference between saturated vapor pressure $\left(\mathrm{VP}_{\mathrm{sat}}\right)$ and measured vapor pressure $\left(\mathrm{VP}_{\text {air }}\right)$ corresponding to maximum air temperature $\left(T_{\max }\right.$, in $\left.{ }^{\circ} \mathrm{C}\right)$, i.e.

$\operatorname{VPD}\left(T_{\max }\right)=\mathrm{VP}_{\mathrm{sat}}\left(T_{\max }\right)-\mathrm{VP}_{\mathrm{air}}$

and

$\mathrm{VP}_{\text {sat }}\left(T_{\max }\right)=0.611 \times 10^{\left(\left(7.5 \times T_{\max }\right) /\left(237.3+T_{\max }\right)\right)}$

$\mathrm{VP}_{\text {air }}=\mathrm{rh} \times \mathrm{VP}_{\text {sat }}\left(T_{\max }\right)$

where rh is the relative humidity (\%).

Surface soil temperature (at $1 \mathrm{~cm}$ depth) is estimated using the following empirical equations:

$\mathrm{ST}_{\text {max }}=T_{\text {max }}+0.962 \times R_{\mathrm{s}}-6.63$

$\mathrm{ST}_{\min }=T_{\min }-0.55$

$\mathrm{ST}_{\mathrm{avg}}=\frac{0.77 \times \mathrm{ST}_{\max }+\mathrm{ST}_{\min }}{2}$

where $\mathrm{ST}_{\max }, \mathrm{ST}_{\min }$ and $\mathrm{ST}_{\text {avg }}$ are the maximum, minimum and average surface soil temperature $\left({ }^{\circ} \mathrm{C}\right)$, respectively, $T_{\max }$ and $T_{\min }$ are the maximum and minimum air temperature $\left({ }^{\circ} \mathrm{C}\right)$, respectively, and $R_{\mathrm{S}}$ the total solar radiation $\left(\mathrm{MJ} \mathrm{m}^{-2} \mathrm{day}^{-1}\right)$.

The belowground average daily soil temperature is calculated for a relatively deep point $(200 \mathrm{~cm})$ using a sinusoidal function given by Campbell (1977; equation 2.8 ) with a mean annual deep soil temperature of $20^{\circ} \mathrm{C}$ $(200 \mathrm{~cm})$, a surface $(-1 \mathrm{~cm})$ annual amplitude of mean daily temperature of $13.7^{\circ} \mathrm{C}$, and an average annual damping depth of $170 \mathrm{~cm}$ (which corresponds to an average thermal diffusivity of $0.003 \mathrm{~cm}^{2} / \mathrm{s}$ ) and a phase adjustment of 91 Julian days for occurrence of mean daily surface $(-1 \mathrm{~cm})$ temperature. This same equation is used to calculate the soil temperature at a shallow point $(50 \mathrm{~cm})$ by including a site-specific harmonic term to account for asymmetry nearer the surface. Soil temperatures at depths from the surface to $50 \mathrm{~cm}$ are determined by interpolation of the logarithmic decay the surface temperature (Eq. (7)) to the predicted daily mean temperature at $50 \mathrm{~cm}$; and soil temperatures from 50 to $200 \mathrm{~cm}$ are predicted by interpolation of the logarithmic decay between these two depths.

\subsection{Soil water distribution and water cycling module}

The water cycling module simulates daily soil evaporation, plant transpiration, and water content and movement in different soil layers (Fig. 1). The water reaching the soil surface of the patch, "effective precipitation" ( $\mathrm{EP}$, in $\mathrm{cmd}^{-1}$ ), is estimated as a function of actual precipitation (Ppt), interception, run on, and run off, i.e.

$\mathrm{EP}=\mathrm{Ppt}-$ intcpt + runon - runoff

intcpt $=\mathrm{SS} \times 2 \times \mathrm{LAI}_{\mathrm{t}}$

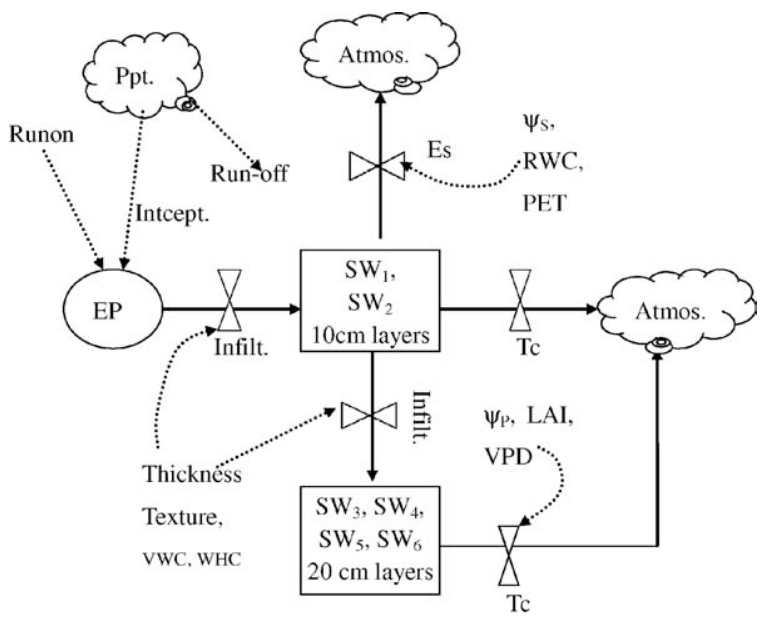

\begin{tabular}{lll}
\hline Abbreviation & Description & Unit \\
\hline Atmos. & Atmosphere & \\
Ppt. & Precipitation & $\mathrm{cm}$ \\
Intcept. & Interception & $\mathrm{cm}$ \\
Infilt. & Infitration & $\mathrm{cm} \mathrm{d}^{-1}$ \\
LAI & Leaf area index & $\mathrm{m}^{2} \mathrm{~m}^{-2}$ \\
PET & Potential evapotranspiration & $\mathrm{cm}$ \\
WHC & Water holding capacity & $\mathrm{cm}$ \\
VWC & Volumetric water content & $\%$ \\
VPD & Vapor pressure deficit & $\mathrm{kPa}$ \\
SW & Soil water content at layer i & $\mathrm{cm}$ \\
Es & Evaporation & $\mathrm{cm} \mathrm{d}$ \\
Tc & Canopy transpiration & $\mathrm{cm} \mathrm{d}$ \\
$\psi_{\mathrm{P}}$ & Water potential of plant & $\mathrm{kPa}^{-1}$ \\
$\psi_{\mathrm{s}}$ & Water potential of soil & $\mathrm{kPa}$ \\
\hline
\end{tabular}

Fig. 1. Flow diagram for water cycling and soil water distribution processes in the PALS-FT model. 
where SS is the surface storage of water film on foliage (ave. for all FTs is ca. $0.02 \mathrm{~cm}$; Reynolds et al., 2000), 2 is a factor accounting for the two sides of the leaf, and $\mathrm{LAI}_{\mathrm{t}}$ is the total leaf area index $\left(\mathrm{m}^{2} \mathrm{~m}^{-2}\right)$ including all plant functional types (as in Kemp et al., 1997). Water run-on and run-off in the simulated patch were not considered because of the negligible slope $(<1 \%)$ in northwestern Phoenix and our testing site (Fig. 4).

Soil water is represented in 6 layers in the PALS-FT model: the upper two layers with a depth of $10 \mathrm{~cm}$ each and the other 4 layers with a depth of $20 \mathrm{~cm}$ each. Water infiltration of each layer is determined by the amount of water percolating out of the upper layer, previous water content, and water holding capacity (WHC) of the layer. Water is removed from the two top layers by evaporation and from all layers by transpiration. Evaporation is determined by soil water availability (soil water potential and relative water content, RWC) and energy available at the soil surface. Water taken up by plants is partitioned among the soil layers according to the proportions of roots in each layer for all FTs. Actual canopy transpiration is estimated by a simple energy budget model and a canopy stomatal resistance function (Kemp et al., 1997; Reynolds et al., 2000).

\subsection{Plant production module}

PALS-FT's plant production module simulates plant phenology, growth, and $\mathrm{C}$ allocation to different plant parts (Fig. 2). Plant growth, litter fall, and plant mortality are influenced by FT-specific patterns of phenology that are controlled by water availability and extreme temperatures. The plant production module for C3 and C4 annuals and perennial grasses differs slightly from Fig. 2 in its inclusion of seed germination and reproduction for the annual FTs and regrowth from roots/rhizomes for grasses. The amount of daily plant growth for all FTs $\left(G_{j}\right.$, in $\mathrm{g}$ dry mass $\left.\mathrm{m}^{-2}\right)$ is calculated in the same way:

$$
\begin{aligned}
G_{i}= & X_{\mathrm{lvs}} \times \mathrm{SLA} \times A_{\max , j} \times \frac{12}{0.46} \times\left(1-R_{\mathrm{loss}}\right) \\
& \times F_{\mathrm{c}} \times F_{\mathrm{t}}
\end{aligned}
$$

where $X_{\text {lvs }}$ is the leaf dry mass (g), SLA the specific leaf area $\left(\mathrm{m}^{2} \mathrm{~g}^{-1}\right), A_{\max , j}$ the maximum potential net photosynthetic rate $\left(\mathrm{mol} \mathrm{CO} \mathrm{Cm}_{2} \mathrm{~m}^{-2} \mathrm{~s}^{-1}\right)$, the value of 12 is the mass of $12 \mathrm{~g} \mathrm{C} / \mathrm{mol} \mathrm{CO}_{2}, 0.46$ is the average
C content (46\%) in plant tissues, $R_{\text {loss }}$ the respiratory loss of photosynthetic production per day, $F_{\mathrm{t}}$ the temperature influence factor (for forbs and grasses, not for shrubs), and $F_{\mathrm{c}}(=2 / \pi \times$ photoperiod $\times 3600)$ is a conversion factor (changing time unit from second to day; Monteith and Unsworth, 1990). The annual growth of plants calculated from Eq. (10) can be summed over the year (or season for annual FTs) and reduced by allocation to above-ground plant material to obtain a measure of aboveground net primary productivity (ANPP; herbivory is considered insignificant in the model).

$A_{\max , j}$ is estimated using the following equation (Ehleringer, 1983):

$A_{\max , j}=\frac{g_{j}}{1.6} \times \frac{\mathrm{Ca}-\mathrm{Ci}_{j}}{p}$

where $g_{j}$ is the stomatal conductance $\left(\mathrm{mol} \mathrm{H}_{2} \mathrm{O}\right.$ $\mathrm{m}^{-2} \mathrm{~s}^{-1}$ ), Ca the partial pressure of atmospheric $\mathrm{CO}_{2}$ concentration $(\mathrm{kPa})$, and $\mathrm{Ci}_{j}$ the partial pressure of intercellular $\mathrm{CO}_{2}(\mathrm{kPa}), 1.6$ is the ratio of diffusivity of $\mathrm{H}_{2} \mathrm{O}\left(21.2 \times 10^{-6}\right)$ to $\mathrm{CO}_{2}\left(12.9 \times 10^{-6}\right), p$ is the atmospheric vapor pressure $(\mathrm{kPa})$ The value of $\mathrm{Ci}_{j}$ is assumed to be determined by the physiological/anatomical capacity of each FT $\left(\mathrm{Ci}_{\min , j}\right)$, and is assumed to be affected by leaf $\mathrm{N}$ levels $\left(S_{j}^{\mathrm{N}}\right)$ :

$\mathrm{Ci}_{j}=\mathrm{Ca}-\left(\mathrm{Ca}-\mathrm{Ci}_{\min , j}\right) \times S_{j}^{\mathrm{N}}$

and $S_{j}{ }^{\mathrm{N}}$ is a linear scalar accounting for the effect of leaf $\mathrm{N}$ on $\mathrm{Ci}_{j}$ of $\mathrm{FT}_{\mathrm{j}} . S_{j}^{\mathrm{N}}$ is defined as:

$$
S_{j}^{\mathrm{N}}= \begin{cases}1 & \text { if } N_{\mathrm{L}}>1 \\ 0.1 & \text { if } N_{\mathrm{L}}<0.1 \\ \frac{N^{\text {leaf }}-N_{\text {min }}^{\text {leaf }}}{N_{\text {max }}^{\text {leaf }}-N_{\text {min }}^{\text {leaf }}}\left(=N_{\mathrm{L}}\right) & \text { if } 0.1 \leq N_{\mathrm{L}} \leq 1\end{cases}
$$

where $N^{\text {leaf }}$ is the currently simulated leaf $N$ fraction, and $N_{\max }^{\text {leaf }}$ and $N_{\min }^{\text {leaf }}$ are the maximum and minimum possible leaf $N$ fractions. Calculation of $A_{\max }$ requires a value for stomatal conductance $\left(g_{j}\right)$. While many photosynthesis models employ schemes for predicting $g$ in relation to feedback from carbon uptake (e.g. Ball et al., 1987; Leuning, 1995), other successful stomatal models have considered that $g$ is a function of leaf water potential, VPD, light, or temperature (e.g. Jarvis, 1976; Oren et al., 1999). The PALS-FT model assumes that the overriding factors controlling stomatal conductance 


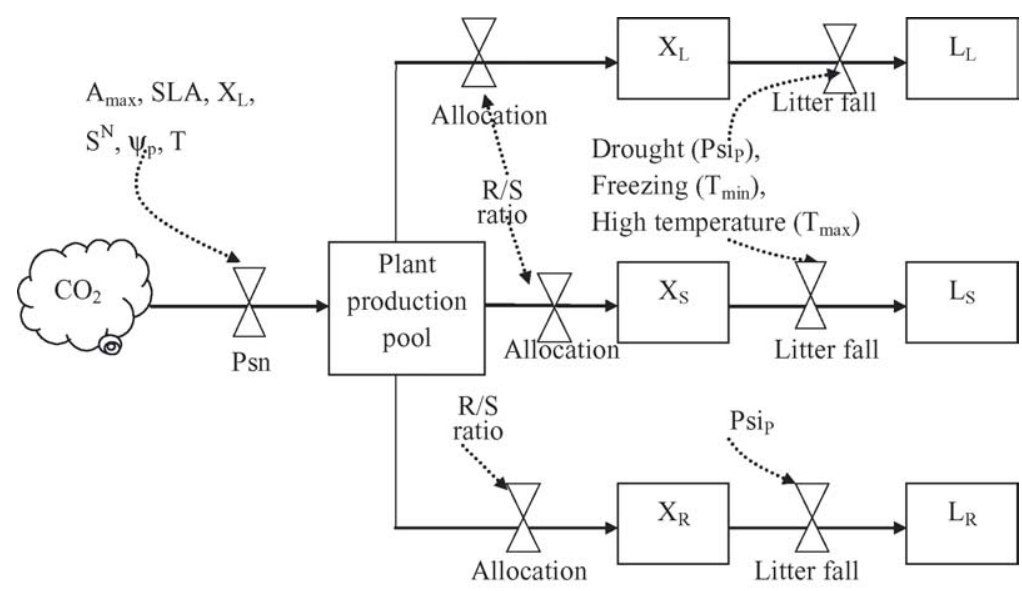

\begin{tabular}{lll}
\hline Abbreviation & Description & Unit \\
\hline$X_{\mathrm{L}}$ & Leaf biomass & $\mathrm{g} \mathrm{DM} \mathrm{m}^{-2}$ \\
$\mathrm{X}_{\mathrm{S}}$ & Stem biomass & $\mathrm{g} \mathrm{DM} \mathrm{m}^{-2}$ \\
$\mathrm{X}_{\mathrm{R}}$ & Root biomass & $\mathrm{g} \mathrm{DM} \mathrm{m}^{-2}$ \\
$\mathrm{~L}_{\mathrm{L}}$ & Leaf litter & $\mathrm{g} \mathrm{DM} \mathrm{m}^{-2}$ \\
$\mathrm{~L}_{\mathrm{S}}$ & Stem litter & $\mathrm{g} \mathrm{DM} \mathrm{m}^{-2}$ \\
$\mathrm{~L}_{\mathrm{R}}$ & Root litter & $\mathrm{g} \mathrm{DM} \mathrm{m}^{-2}$ \\
Psn & Photosynthetic rate & $\mathrm{g} \mathrm{DM} \mathrm{m}^{-2} \mathrm{~d}^{-1}$ \\
$\mathrm{~A}_{\max }$ & Maximum potential net & $\mathrm{mol} \mathrm{CO}_{2} \mathrm{~m}^{-2} \mathrm{~s}^{-1}$ \\
& photosynthetic rate & \\
$\mathrm{DM}$ & Dry mass & $\mathrm{g}^{2}$ \\
$\mathrm{SLA}$ & Specific leaf area & $\mathrm{m} \mathrm{g}^{-1}$ \\
$\psi_{\mathrm{P}}$ & Water potential of plant & $\mathrm{kPa}$ \\
Psi & $-\psi$ & $\mathrm{kPa}$ \\
$\mathrm{T}$ & Temperature & ${ }^{\circ} \mathrm{C}$ \\
$\mathrm{R} / \mathrm{S}$ & Root-shoot ratio & Fraction \\
$\mathrm{S}^{\mathrm{N}}$ & Scalar for N effects & Fraction \\
\hline
\end{tabular}

Fig. 2. Schematic diagram of plant production module for shrubs in the PALS-FT model.

in desert plants is plant water potential (leaf hydration) and atmospheric vapor deficit (see Kemp et al., 1997). Thus, $g_{j}$ is calculated as an exponential function of FT leaf water potential $\left(\Psi_{j}\right)$ with a linear relationship to decreasing atmospheric vapor deficit (VPD in $\mathrm{kPa}$ ):

$g_{j}=a \times \mathrm{e}^{\left(b \times \Psi_{j}\right)} \times(1-0.1 \times \mathrm{VPD})$

with $a$ and $b$ as FT-specific parameters defining the exponential decline in $g_{j}$ with decreasing $\Psi_{j}$ (Table A.2). A daily value for leaf water potential of each FT $\left(\Psi_{j}\right)$ is calculated from the water potential of all soil layers weighted by the fraction of roots of each FT in each specific layer (see Kemp et al., 1997).

\subsection{Nutrient cycling module}

The nutrient cycling module simulates the dynamics of $\mathrm{C}$ and $\mathrm{N}$ in the soil-plant-atmosphere system (Fig. 3), and is a modified version of the nutrient cycling part of the CENTURY model (Parton et al., 1988, 1993). Three kinds of plant litter are distinguished for each of the FTs: leaf litter, stem litter, and root litter; with the leaf and stem litter being allocated to one of two chemical pools on the soil surface (metabolic or structural C) and root litter being allocated to one of two pools in the belowground soil (also metabolic or structural C). The partitioning of litter into metabolic or structural fractions was based on literature values of residual chemical composition 


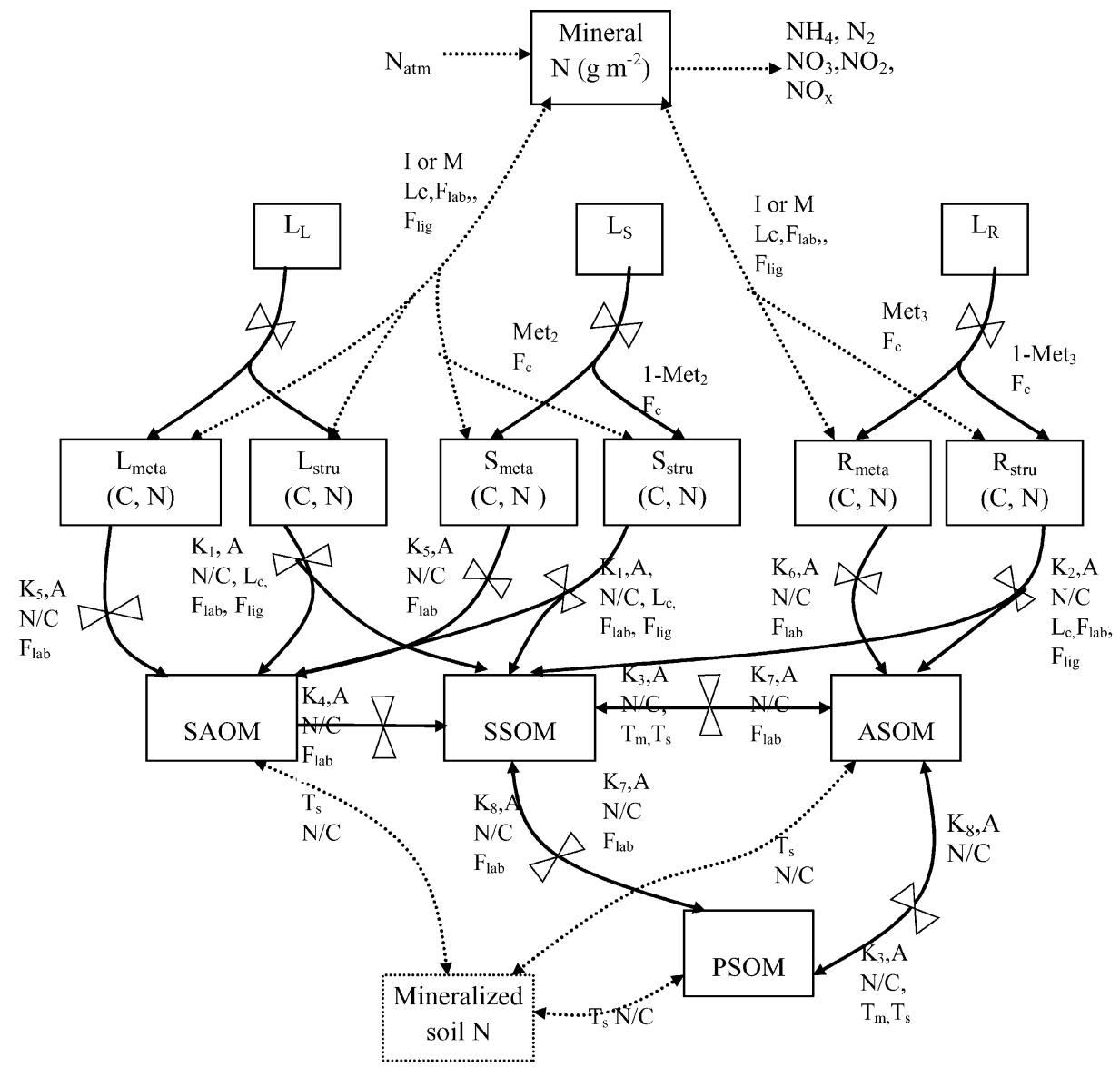

\begin{tabular}{|c|c|c|c|c|c|}
\hline $\begin{array}{l}\text { Abbreviation/ } \\
\text { Symbol }\end{array}$ & Description & Unit & $\begin{array}{l}\text { Abbreviation/ } \\
\text { Symbol }\end{array}$ & Description & Unit \\
\hline 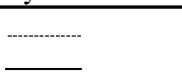 & $\begin{array}{l}\text { Only nitrogen flow } \\
\text { Both C and N flow }\end{array}$ & & $\begin{array}{l}\mathrm{N}_{\mathrm{atm}} \\
\mathrm{NH}_{4}, \mathrm{~N}_{2}, \mathrm{NO}_{\mathrm{x}}\end{array}$ & $\begin{array}{l}\text { Atmospheric } \mathrm{N} \text { deposition } \\
\text { Mineral Nitrogen }\end{array}$ & $\begin{array}{l}\mathrm{g} \mathrm{m}^{-2} \mathrm{~d}^{-1} \\
\mathrm{~g} \mathrm{~m}^{-2}\end{array}$ \\
\hline $\mathrm{L}_{\mathrm{L}}$ & Leaf litter & $\mathrm{g} \mathrm{DM} \mathrm{m}^{-2}$ & $\mathrm{~K}_{\mathrm{i}}, \mathrm{i}=1,2,---, 8$ & \multirow{4}{*}{\multicolumn{2}{|c|}{$\begin{array}{l}\text { Decomposition rates } \\
\text { Immobilization }\end{array}$}} \\
\hline $\mathrm{L}_{\mathrm{S}}$ & Stem litter & $\mathrm{g} \mathrm{DM} \mathrm{m}^{-2}$ & I & & \\
\hline $\mathrm{L}_{\mathrm{R}}$ & Root litter & $\mathrm{g} \mathrm{DM} \mathrm{m}^{-2}$ & M & & \\
\hline $\mathrm{L}_{\text {meta }}$ & Leaf metabolic $\mathrm{C}, \mathrm{N}$ & $\mathrm{g} \mathrm{m}^{-2}$ & $\mathrm{~N} / \mathrm{C}$ & & \\
\hline $\mathrm{L}_{\text {stru }}$ & Leaf structural $\mathrm{C}, \mathrm{N}$ & $\mathrm{g} \mathrm{m}^{-2}$ & $\operatorname{Met}_{\mathrm{i}} \mathrm{i}=1,2,--, 4$ & \multicolumn{2}{|c|}{ Fraction of metabolic material in litter mass } \\
\hline $\mathrm{S}_{\text {meta }}$ & Stem metabolic C, N & $\mathrm{g} \mathrm{m}^{-2}$ & $\mathrm{~L}_{\mathrm{c}}$ & \multicolumn{2}{|c|}{ Effect of lignin content on decomp } \\
\hline$S_{\text {stru }}$ & Stem structural C, N & $\mathrm{g} \mathrm{m}^{-2}$ & A & Effect of soil abiotic conditic & on decomposition \\
\hline $\mathrm{R}_{\text {meta }}$ & Root metabolic C, N & $\mathrm{g} \mathrm{m}^{-2}$ & $\mathrm{~T}_{\mathrm{m}}$ & \multirow{2}{*}{\multicolumn{2}{|c|}{$\begin{array}{l}\text { Effect of soil texture on ASOM turnover } \\
\text { Effect of soil texture on organic N decomposition }\end{array}$}} \\
\hline $\mathrm{R}_{\text {stru }}$ & Root structural C, N & $\mathrm{g} \mathrm{m}^{-2}$ & $\mathrm{~T}_{\mathrm{s}}$ & & \\
\hline SAOM & Surface active organic matter & $\mathrm{g} \mathrm{m}^{-2}$ & $\mathrm{~F}_{\mathrm{c}}$ & \multirow{2}{*}{\multicolumn{2}{|c|}{$\begin{array}{l}\text { Fraction of carbon in litter mass } \\
\text { Fraction of } \mathrm{N} \text { mineralized from labile material }\end{array}$}} \\
\hline SSOM & Slow soil organic matter & $\mathrm{g} \mathrm{m}^{-2}$ & $\mathrm{~F}_{\text {lab }}$ & & \\
\hline ASOM & Active soil organic matter & $\mathrm{g} \mathrm{m}^{-2}$ & $\mathrm{~F}_{\text {lig }}$ & \multirow{2}{*}{\multicolumn{2}{|c|}{ Fraction of $\mathrm{N}$ mineralized from lignin and cellulose }} \\
\hline PSOM & Passive soil organic matter & $\mathrm{g} \mathrm{m}^{-2}$ & & & \\
\hline
\end{tabular}

Fig. 3. Schematic diagram of nutrient cycling module in the PALS-FT model. 
of litter types for each FT (see Kemp et al., 2003):

$\frac{\mathrm{d} C_{\mathrm{m}, i}}{\mathrm{~d} t}=\sum_{j=1}^{6} \frac{\mathrm{d} L_{i, j}}{\mathrm{~d} t} \times \operatorname{Met}_{i, j} \times F_{\mathrm{c}, j}$,

for metabolic material

$\frac{\mathrm{d} C_{\mathrm{s}, i}}{\mathrm{~d} t}=\sum_{j=1}^{6} \frac{\mathrm{d} L_{i, j}}{\mathrm{~d} t} \times\left(1-\operatorname{Met}_{i, j}\right) \times F_{\mathrm{c}, j}$

for structural material

where $i=1,2,3$ for leaf, stem and root, $j=1,2,3,4$, 5, 6 for the 6 plant functional types, $C_{\mathrm{m}, i}$ and $C_{\mathrm{s}, i}$ are the $C$ contents $(g)$ in metabolic and structural material, respectively, $L_{i, j}$ is the litter dry mass in each litter type i-FT $\mathrm{F}_{\mathrm{j}}$ combination, $\mathrm{Met}_{i, j}$ is the fraction of metabolic material, and $F_{\mathrm{c}, j}$ is the fraction of $\mathrm{C}$ content of litter type $i$ (in dry mass) of $\mathrm{FT}_{j}$.

The input rates of $\mathrm{N}$ from plant litter to metabolic $\left(N_{\mathrm{m}}\right)$ and structural material $\left(N_{\mathrm{s}}\right)$ pools are modeled similarly to $C$ :

$\frac{\mathrm{d} N_{\mathrm{m}, i}}{\mathrm{~d} t}=\left(\sum_{j}^{6} \frac{\mathrm{d} L_{i, j}}{\mathrm{~d} t} \times N_{i, j}\right)-\frac{\mathrm{d} N_{\mathrm{s}, i}}{\mathrm{~d} t}$,

for metabolic material

$\frac{\mathrm{d} N_{\mathrm{s}, i}}{\mathrm{~d} t}=\sum_{j=1}^{6} \frac{\mathrm{d} L_{i, j}}{\mathrm{~d} t} \times\left(1-\operatorname{Met}_{i, j}\right) \times F_{\mathrm{c}, j} \times\left(\frac{N}{C}\right)_{i, j}$,

for structural material

where $i, j, L_{i, j}, F_{\mathrm{c}, j}$, and $\mathrm{Met}_{i, j}$ are the same as in Eqs (15) and (16), $N_{i, j}$ is the $N$ content (\% of dry mass) of litter type $i$ of $\mathrm{FT}_{j}$, and $(N / C)_{i, j}$ is the ratio of $\mathrm{N}$ to $\mathrm{C}$ for litter type $i$ of $\mathrm{FT}_{j}$.

After decomposition, the metabolic and structural material of plant litter enters into one of the three soil organic matter (SOM) pools: surface litter enters the surface active organic matter (SAOM), and belowground litter enters the active soil organic matter (ASOM) or slow soil organic matter (SSOM) according to the partitioning scheme employed in CENTURY (Parton et al., 1993), and a small fraction of the C from the soil organic matter pools enters the passive soil organic matter (PSOM). The flows of C from metabolic and structural material pools to the three SOM pools and among the SOM pools are depicted in Fig. 3 and are defined by the following differential equations (Parton et al., 1993):

$\frac{\mathrm{d} C_{i}}{\mathrm{~d} t}=K_{i} \times L_{\mathrm{C}} \times A \times C_{i}, \quad i=1,2$

$\frac{\mathrm{d} C_{i}}{\mathrm{~d} t}=K_{i} \times A \times T_{\mathrm{m}} \times C_{i}, \quad i=3$

$\frac{\mathrm{d} C_{i}}{\mathrm{~d} t}=K_{i} \times A \times C_{i}, \quad i=4,5,6,7,8$

where $C_{i}$ is the $C$ in the state variable $i ; i=1,2,3$, $4,5,6,7,8$ denote surface (leaf and stem) structural material, root structural material, active soil organic matter, surface-active organic matter, surface metabolic material, soil metabolic material, slow soil organic matter fractions, and passive soil organic matter fractions, respectively; $K_{i}$ is the maximum decomposition rate $\left(\right.$ day $\left.^{-1}\right)$ for the $i$ th state variable (Table A.1); $L_{\mathrm{C}}$ the impact of lignin content of structural material on its decomposition, $T_{\mathrm{m}}$ is the effect of soil texture on ASOM turnover, and $A$ is the combined abiotic impact of soil moisture and soil temperature on decomposition (product of the soil moisture and temperature terms). Calculations of $L_{\mathrm{C}}, T_{\mathrm{m}}$, and $A$ are as in Parton et al. (1993).

The dynamics of $\mathrm{N}$ in decomposing organic matter is coupled directly to the flows of $\mathrm{C}$ through the various $\mathrm{SOM}$ pools. The flow of $\mathrm{N}$ among these pools is equal to the product of the $\mathrm{C}$ flows and the $\mathrm{N} / \mathrm{C}$ ratio of the recipient state variable (Parton et al., 1993). Specifically, the following differential equations describe the dynamics of organic $\mathrm{N}$ among different pools:

$$
\begin{aligned}
\frac{\mathrm{d} N_{i}}{\mathrm{~d} t}= & \left(1-\left(\frac{L}{S}\right)_{i}\right) \times\left(1-F_{\text {lab,min }}\right) \times \frac{\mathrm{d} C_{i}}{\mathrm{~d} t} \\
& \times\left(\frac{N}{C}\right)_{i}+\left(\frac{L}{S}\right)_{i} \times\left(1-F_{\text {lig }, \text { min }}\right) \\
& \times \frac{\mathrm{d} C_{i}}{\mathrm{~d} t} \times\left(\frac{N}{C}\right)_{i} \quad i=1,2
\end{aligned}
$$

$$
\frac{\mathrm{d} N_{i}}{\mathrm{~d} t}=\left(1-T_{\mathrm{m}}\right) \times \frac{\mathrm{d} C_{i}}{\mathrm{~d} t} \times\left(\frac{N}{C}\right)_{i} i=3
$$




$$
\begin{aligned}
& \frac{\mathrm{d} N_{i}}{\mathrm{~d} t}=\left(1-F_{\text {lab,min }}\right) \times \frac{\mathrm{d} C_{i}}{\mathrm{~d} t} \times(N / C)_{i} \\
& i=4,5,6,7,8
\end{aligned}
$$

where $N_{i}$ is $\mathrm{N}$ in state variable $i ; i$ represent the same organic pools as in Eqs. (19)-(21); $(L / S)_{i}$ the ratio of lignin content to the summation of lignin and cellulose material in the $i$ th organic pool (Table A.2); $(N / C)_{i}$ the ratio of $N$ to $C$ for the $i$ th organic matter pool and calculated in each time step of simulation; $F_{l a b, \min }$ is the fraction of $\mathrm{N}$ in labile material lost due to microbial respiration (Table A.2); $F_{\text {lig,min }}$ is the fraction of $N$ in non-labile material (i.e. lignin and cellulose) lost due to microbial respiration (Table A.2); $T_{\mathrm{s}}$ the effect of soil texture on organic $N$ turnover (Parton et al., 1993).

For different organic matter pools, $N$ associated with $C$ lost in respiration is assumed to be mineralized. Nitrogen mineralization rates are also the products of the decomposition rates $\left(\mathrm{d} C_{\mathrm{i}} / \mathrm{d} t\right)$ of corresponding carbon pools, the fraction of respiratory $N$ loss $\left(F_{\text {lab,min }}\right)$, and $N / C$ ratio. Thus, we have:

$$
\begin{aligned}
\frac{\mathrm{d} N_{i, \min }}{\mathrm{d} t}= & \left(1-\left(\frac{L}{S}\right)_{i}\right) \times\left(F_{\text {lab }, \text { min }}\right) \times \frac{\mathrm{d} C_{i}}{\mathrm{~d} t} \\
& \times\left(\frac{N}{C}\right)_{i}+\left(\frac{L}{S}\right)_{i} \times\left(F_{\text {lig, min }}\right) \times \frac{\mathrm{d} C_{i}}{\mathrm{~d} t} \\
& \times\left(\frac{N}{C}\right)_{i} i=1,2
\end{aligned}
$$

$$
\begin{aligned}
& \frac{\mathrm{d} N_{i, \min }}{\mathrm{d} t}=T_{\mathrm{s}} \times \frac{\mathrm{d} C_{i}}{\mathrm{~d} t} \times\left(\frac{N}{C}\right)_{i} i=3,4 \text { if } \frac{N}{C}>\frac{1}{8}, \\
& \text { or } i=7,8 \text { if } \frac{N}{C}>\frac{1}{11}, \text { otherwise, } \frac{\mathrm{d} N_{i, \min }}{\mathrm{d} t}=-0.02
\end{aligned}
$$

$$
\frac{\mathrm{d} N_{i, \min }}{\mathrm{d} t}=F_{\mathrm{lab}, \min } \times \frac{\mathrm{d} C_{i}}{\mathrm{~d} t} \times\left(\frac{N}{C}\right)_{i} i=5,6
$$

where $N_{i, \min }$ is the $N$ loss from the $i$ th organic matter pool through mineralization, and all other parameters are the same as in Eqs. (22)-(24).

\section{Model parameterization}

The study area is located northwest of Phoenix, Arizona, USA, within the Central Arizona-Phoenix Long Term Ecological Research (CAP LTER) study area (Fig. 4). The Sonoran Desert scrub biome occupies most of southwestern Arizona below $1050 \mathrm{~m}$ (Turner and Brown, 1994). Shreve (1951) recognized seven vegetation subdivisions in the Sonoran Desert, two of which occur in the CAP LTER study area: Lower Colorado River Valley subdivision and Arizona upland subdivision. The lower Colorado River Valley subdivision occupies most of the CAP LTER study area, particularly in the northwestern portion, and is dominated by creosotebush (Larrea tridentata) and triangle-leaf bursage (Ambrosia deltoidea; Turner and Brown, 1994; MacMahon, 2000). The Arizona upland subdivision occurs in the northeastern part of the CAP LTER study area and is dominated by paloverde (Cercidium microphyllum) and cacti (Carnegiea gigantea, Opuntia spp), with creosotebush and bursage common as well. The rest of the CAP LTER study area is composed mainly of agricultural, urban, and riparian lands. In this study, we focus on the Larrea and Ambrosia co-dominated communities.

We have classified input data to PALS-FT into two groups: site-specific parameters and plantecophysiological parameters. Site parameters include climatic variables, living and dead plant biomass (initial values of state variables), and soil properties (e.g. texture, organic matter content) (Table A.1). The plant-ecophysiological parameters include distribution of plant root fractions in different soil layers, specific leaf area, respiratory loss ratios of daily production, minimum leaf intercellular $\mathrm{CO}_{2}$, contents of $\mathrm{N}, \mathrm{C}$, lignin and cellulose in leaves, stems and roots, and production allocation ratios (Table A.2). The two kinds of parameter values were obtained from three sources: the CAP LTER 200-point field survey data, literature, and values used in the original PALS-FT model. The 200-point survey data were the major source for site-specific parameters, although climatic data were obtained from the Wadell Weather Station, which is located in the northwest fringe of metropolitan Phoenix about $50 \mathrm{~km}$ from the urban center (Fig. 4).

The 200-point survey data were obtained from an extensive field survey with 204 sample plots $(30 \mathrm{~m} \times 30 \mathrm{~m})$ throughout the metropolitan area, 


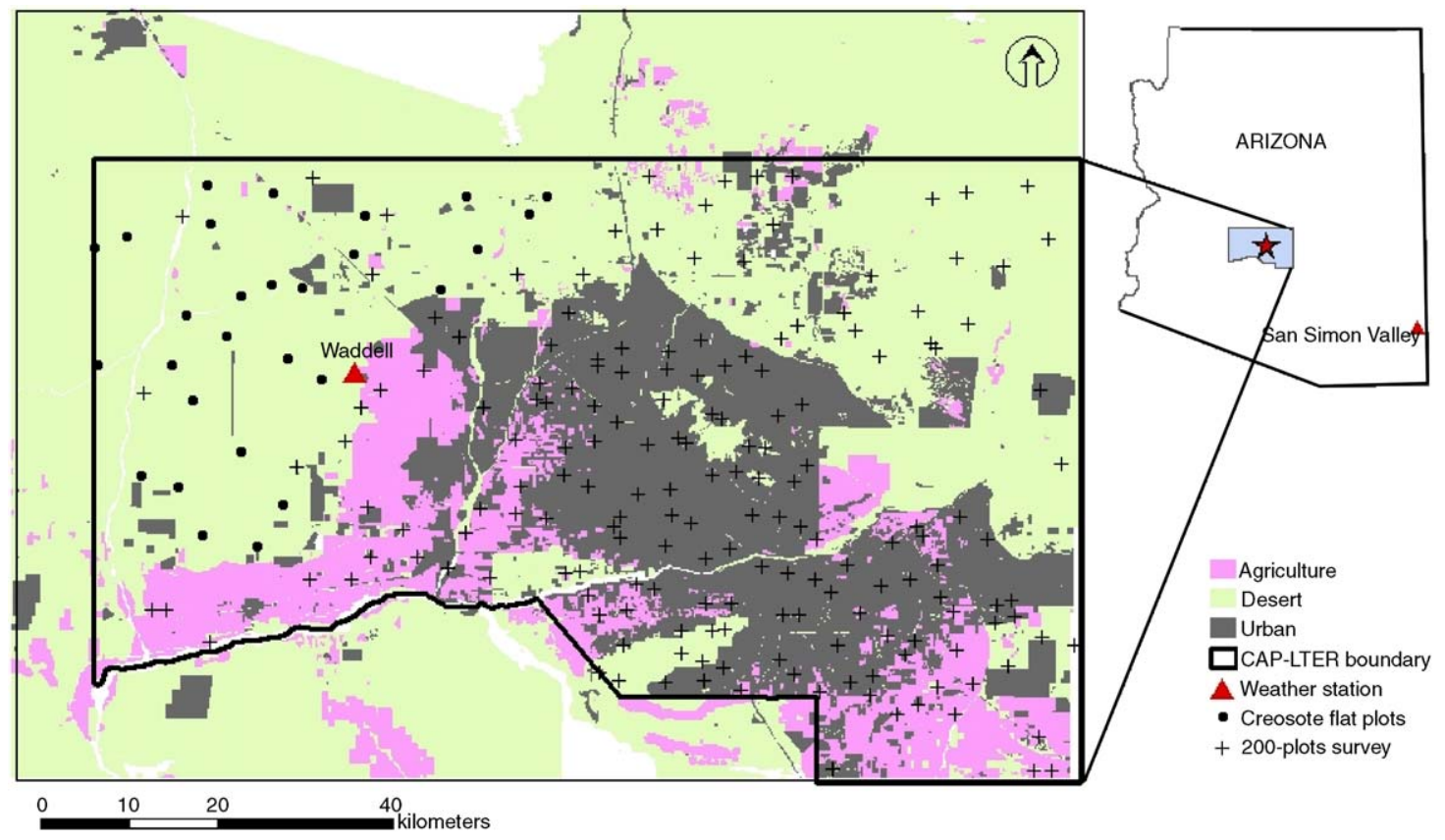

Fig. 4. Maps showing the research sites of this study. Solid dots represent sampling plots of the Larrea ecosystem in the CAP LTER research area. Solid triangles represent the positions of weather stations from where the meteorological data were obtained for driving the PALS-FT model. The San Simon Valley is site of Chew and Chew's (1965) field study of biomass and NPP of a Larrea ecosystem, which was used to validate the model.

which was carried out by CAP LTER over a 3-month period in spring 2000 (Hope et al., 2003). In order to obtain a spatially dispersed and unbiased sample that allows for maximum post-design extrapolation, a dual-density randomized tessellation stratified design was used to locate the sample plots. At each location, a systematic, integrated field inventory of key abiotic, biotic, and human variables was carried out. Within each plot all woody plants (trees, shrubs, cacti, succulents) were identified, and the canopy dimensions of each individual measured to give the total volume of woody plant material. Five soil cores were taken at each site, which each were separated into $0-10 \mathrm{~cm}$ and $11-30 \mathrm{~cm}$ sections. Soil samples were analyzed to determine moisture content, organic matter content, bulk density, particle size distribution, $\mathrm{pH}$, readily leachable soil nitrate and phosphate content, and inorganic and organic $\mathrm{C}$ content. Other measured variables included meteorological conditions, land-use and land-cover types, insect populations, surface pollens, and prokaryote and mycorrhizal diversity. In addition, information was also obtained on elevation, distance from urban center, distance from the nearest major freeway, land-use history, median family income, average age of housing stock, and human population density.

PALS-FT distinguishes between living and dead biomass. The 200-point survey data only provide total vegetation cover for each plot. In order to estimate the biomass of each of the six plant functional types, we first derived an average vegetation coverage (32.9\%) based on the measures in 30 of the 204 plots (see Fig. 4), and then calculated the plant cover of individual FTs as the product of the average total cover and the relative cover of each FT which was measured in the same area by Camp (1986). Then, the total aboveground biomass of each FT was estimated based on empirical coverbiomass relations (Table 1). Further, the biomass of leaves, stems, and roots of perennial FTs (i.e. perennial grass, subshrub and shrub) was calculated using biomass-allocation ratios derived from Chew and Chew (1965). The dead biomass was calculated according to the dead to living biomass ratio used in the original PALS-FT model. Plant litter is split into metabolic and structural material. We estimated the size of the two 
Table 1

Species composition, vegetation cover, and biomass of different plant functional types in the Larrea community in northwestern Phoenix

\begin{tabular}{|c|c|c|c|c|c|c|c|}
\hline Functio-nal type & Plant species & $\begin{array}{l}\text { Relative } \\
\operatorname{cover}^{\mathrm{a}}(\%)\end{array}$ & $\begin{array}{l}\text { Ground } \\
\text { cover }(\%)\end{array}$ & $\begin{array}{l}\text { Cover-biomass } \\
\text { relation }{ }^{\mathrm{b}}\end{array}$ & $\begin{array}{l}\text { Above-ground } \\
\text { biomass } \\
\left(\mathrm{AGB}, \mathrm{g} \mathrm{m}^{-2}\right)\end{array}$ & $\begin{array}{l}\text { Biomass allocation } \\
\text { ratio }^{c}\end{array}$ & $\begin{array}{l}\text { Ratio of dead } \\
\text { biomass to live } \\
\text { biomass }^{\mathrm{b}}\end{array}$ \\
\hline Shrub & $\begin{array}{l}\text { Larrea tridentata, Fouquieria } \\
\text { splendens, Krameria grayi }\end{array}$ & 40 & 13.2 & Cover $=\mathrm{AGB} / 1586$ & 209.1 & $\begin{array}{l}0.18 \text { (leaf) } 0.57 \\
\text { (stem) } 0.25 \text { (root) }\end{array}$ & $\begin{array}{l}0.2 \text { (leaf) } 0.2 \text { (stem) } \\
0.2 \text { (root) }\end{array}$ \\
\hline Sub- shrub & $\begin{array}{l}\text { Ambrosia deltoidea, Ambrosia } \\
\text { dumosa, Encelia farinosa }\end{array}$ & 25 & 8.2 & Cover $=\mathrm{AGB} / 744$ & 61.3 & $\begin{array}{ll}0.22 & \text { (leaf) } \quad 0.54 \\
\text { (stem) } & 0.24 \text { (root) }\end{array}$ & $\begin{array}{l}0.1 \text { (leaf) } 0.5 \text { (stem) } \\
0.2 \text { (root) }\end{array}$ \\
\hline Perennial grass & $\begin{array}{l}\text { Pleuarphis rigida, Pennisetum } \\
\text { setaceum }\end{array}$ & 10 & 3.3 & Cover $=$ AGB $/ 240$ & 7.9 & $\begin{array}{lll}0.63 & \text { (leaf) } & 0.37 \\
\text { (root) } & & \end{array}$ & 1.3 (leaf) 2.0 (root) \\
\hline Forb & $\begin{array}{l}\text { Baileya multiradiata, } \\
\text { Dimorphocarpa wislizenii }\end{array}$ & 15 & 4.9 & $\begin{array}{l}\text { Cover } \\
=0.01 \mathrm{AGB}+2.3 \\
\times 10^{-5} \mathrm{AGB}^{\mathrm{b}}\end{array}$ & 0.2 & - & - \\
\hline $\mathrm{C} 3$ winter annual & $\begin{array}{l}\text { Daucus pusillus, Plantago } \\
\text { fastigiata }\end{array}$ & 7 & 2.3 & $\begin{array}{l}\text { Cover } \\
=0.01 \mathrm{AGB}+2.3 \\
\times 10^{-5} \mathrm{AGB}^{\mathrm{b}}\end{array}$ & 0.1 & - & - \\
\hline $\mathrm{C} 4$ summer annual & $\begin{array}{l}\text { Tidestromia, lanuginosa } \\
\text { Pectis papposa }\end{array}$ & 3 & 1.0 & $\begin{array}{l}\text { Cover } \\
=0.01 \mathrm{AGB}+2.3 \\
\times 10^{-5} \mathrm{AGB}^{\mathrm{b}}\end{array}$ & 0 & - & - \\
\hline
\end{tabular}


litter pools by multiplying the total litter with their respective relative proportions for leaves, stems, and roots as used in the original PALS-FT model. Average SOM was estimated from the field survey data, and its relative organic $\mathrm{C}$ content $(0.13 \%)$ was converted to $\mathrm{C}(\mathrm{g})$ per unit area $\left(\mathrm{m}^{2}\right)$ based on soil bulk density $\left(1.25 \mathrm{~g} \mathrm{~cm}^{-3}\right)$ and rooting depth $(100 \mathrm{~cm})$. This resulted in an average soil organic $\mathrm{C}$ of $1625 \mathrm{~g} \mathrm{C} \mathrm{m}^{-2}$ in the Larrea-Ambrosia community ( $N=30$ plots). The partitioning of the total soil organic $\mathrm{C}$ into the different SOM pools was determined as in the CENTURY model (Parton et al., 1988; Parton et al., 2001). All the above site-specific parameters are listed in Table A.1. Most of the ecophysiological parameters were determined based on literature and the original PALS-FT model, which was used to analyze the effect of rainfall variability on the hydrologic cycle of the Chihuahuan Desert ecosystem (Reynolds et al., 2000). The values of these parameters are listed in Table A.2.

\section{Model evaluation}

Model evaluation usually refers to verification and validation, but may also include model calibration and sensitivity analysis (Swartzman and Kaluzny, 1987; Rykiel, 1996). Model verification is performed to ascertain the correctness of the mathematical formalism and computer code, whereas model validation is the process of evaluating the consistency and accuracy of model behavior against observations (Jorgensen, 1986), or a demonstration that a model, within its domain of applicability, possesses a satisfactory range of accuracy consistent with the intended application of the model (Rykiel, 1996). Because the overall model structure and belowground components have been tested elsewhere (e.g. Reynolds et al., 1997, 2000; Kemp et al., 2003), the emphasis here is to evaluate the accuracy of the PALS-FT prediction of ANPP of a typical Sonoran Desert ecosystem against field observations. We emphasize two validation criteria: 1) the agreement between the simulated and observed ANPP for different FTs and the entire ecosystem, and 2) the agreement between the simulated and known seasonal and inter-annual patterns of ANPP in response to precipitation fluctuations. Because available field observations on NPP of arid or semiarid ecosystems are aboveground NPP, we show only simulated above- ground NPP, although the PASL-FT model simulates belowground NPP as well.

\subsection{ANPP at the FT and ecosystem levels}

To assess the accuracy of predicted ANPP at both the FT and ecosystem levels, we first conducted simulations for an independent test site, a Larrea tridentatadominated plant community in the San Simon Valley, southeastern Arizona (Fig. 4), where detailed field measurements of ANPP are available. The San Simon Valley site is representative of the widespread Larreadominated communities of the Sonoran Desert, and similar to our study site northwest of Phoenix in terms of both community structure and soil properties (Table 2). In a 9.3 ha plot, Chew and Chew (1965) estimated the growth rate of $L$. tridentata as the addition of new nodes and its productivity as the product of the per-individual growth rate and the number of individuals for different age classes from June, 1958 to August, 1959. The aboveground productivity of other shrubs (e.g. Parthenium incanum) and grass species was also measured similarly.

We ran the model at a daily time step with the initial values of plant biomass for different functional types based on Chew and Chew (1965) (Table A.3) and the actual meteorological data from the San Simon Valley weather station for the same time period that the field measurements were made. Total soil organic $\mathrm{C}$ was estimated as $2600 \mathrm{~g} \mathrm{C} \mathrm{m}^{-2}$ a based on Kenneth's (1980) investigation on the bulk density and SOM content in the San Simon Valley area (Table 2), and was partitioned into different SOM pools as described in Section 2.4 (values listed in Table A.3). Other model input parameters, including all ecophysiological parameters, are kept the same as in Table A.2. The simulated and observed ANPP for the San Simon Valley test site showed reasonable agreement for different FTs and the community as a whole (Fig. 5a). The relative error of the simulated ANPP was $\pm 2.4 \%$ for the whole community, and generally less than $25 \%$ for different FTs (Fig. 5b). Note that we used winter grass here, including perennial grass, forb, and C3 winter annuals, to represent the "fall crop" in Chew and Chew (1965).

For the study area in northwestern Phoenix where direct field measurements of ANPP are not available, we compared the model-predicted results with those in the literature. The simulations were conducted for 
Table 2

Comparison of climatic, soil and vegetation conditions between the northwestern Phoenix study area and the San Simon Valley test site

\begin{tabular}{|c|c|c|c|}
\hline & Northwestern phoenix & San Simon valley & Sources \\
\hline \multicolumn{4}{|l|}{ Climate } \\
\hline Weather stations and their locations & $\begin{array}{l}\text { Waddell } 33^{\circ} 37^{\prime} 05^{\prime \prime} \mathrm{N} \text {. } \\
\text { Lat. } 112^{\circ} 27^{\prime} 35^{\prime \prime} \text { W. Long. }\end{array}$ & $\begin{array}{l}\text { San Simon } 32^{\circ} 16^{\prime} \text { N. Lat. } \\
109^{\circ} 13^{\prime} \text { W. Long. }\end{array}$ & AZMET and \\
\hline Elevation $(\mathrm{m})$ & 407 & 1100 & WRCC* \\
\hline Mean annual air temperature $\left({ }^{\circ} \mathrm{C}\right)$ & 22.2 & 16.8 & \\
\hline Mean maximum air temperature $\left({ }^{\circ} \mathrm{C}\right)$ & 30.2 & 26.6 & \\
\hline Mean minimum air temperature $\left({ }^{\circ} \mathrm{C}\right)$ & 13.7 & 6.8 & \\
\hline Annual precipitation (mm) & 221.7 & 244.4 & \\
\hline \multicolumn{4}{|l|}{ Soil } \\
\hline Type & $\begin{array}{l}\text { Tremant Gravelly sandy } \\
\text { loams }\end{array}$ & $\begin{array}{l}\text { Kimbrough gravelly fine } \\
\text { sandy loams }\end{array}$ & Kenneth, 1980 \\
\hline Depth $(\mathrm{cm})$ & $80-150$ & $40-60$ & \\
\hline Bulk density $\left(\mathrm{g} \mathrm{cm}^{-3}\right)$ & 1.25 & 1.30 & Camp, 1986 \\
\hline Clay content $(\%)$ & 12.6 & 17.4 & \\
\hline Volumetric water content $(\%)$ & $7.5-11$ & $10-17$ & \\
\hline Soil organic matter $(\%)$ & 0.23 & 1.0 & \\
\hline \multicolumn{4}{|l|}{ Plant community } \\
\hline Community type & Larrea & Larrea & $\begin{array}{lr}\text { MacMahon, } & 2000 \\
\text { Chew and Chew, } & 1965\end{array}$ \\
\hline Coverage ( $\%$ of surface) & 25.1 & 20.7 & \\
\hline Density (number of individuals/ha) & $\begin{array}{l}448 \text { (Larrea), } 84 \\
\text { (Ambrosia), } 144 \text { (cacti) }\end{array}$ & $\begin{array}{l}446 \text { (Larrea), } 134 \text { (other } \\
\text { shrubs) }\end{array}$ & \\
\hline Dominated species & $\begin{array}{l}\text { Larrea tridentata, } \\
\text { Ambrosia deltoidea }\end{array}$ & Larrea tridentata & \\
\hline Other shrub or cacti species & $\begin{array}{l}\text { Baccharis sarothroides, } \\
\text { Fouquieria splendens, } \\
\text { Encelia farinosa Acacia } \\
\text { greggii }\end{array}$ & $\begin{array}{l}\text { Flourensia cernua, } \\
\text { Parthenium incanum, } \\
\text { Opuntia phaeacantha, } \\
\text { Acacia greggii }\end{array}$ & \\
\hline Perennial grasses & Pleuraphis rigida & $\begin{array}{l}\text { Tridens pulchellus, } \\
\text { Muhlenbergia porteri, } \\
\text { Bahia absinthifolia }\end{array}$ & \\
\hline
\end{tabular}

AZMET denotes the Arizona Meteorological Network, and WRCC the Western Regional Climate Center.

15 years using actual daily meteorological data from 1 January 1988 to 31 December 2002. During the 15 years, annual precipitation fluctuated between $61.8 \mathrm{~mm}$ (1999) and $516.5 \mathrm{~mm}$ (1992) (Fig. 6a). Initial conditions of the Larrea-Ambrosia ecosystem are listed in Tables A.1 and A.2. The simulated 15-year average ANPP of the ecosystem was $72.3 \mathrm{~g} \mathrm{~m}^{-2} \mathrm{y}^{-1}$, ranging from 11.3 to $229.6 \mathrm{~g} \mathrm{~m}^{-2} \mathrm{y}^{-1}$ (Fig. 6a). The simulated mean ANPP was quite close to the observed value $\left(70 \mathrm{~g} \mathrm{~m}^{-2} \mathrm{y}^{-1}\right)$ suggested by Whittaker and Likens (1973) for desert scrub communities (also see Ludwig, 1987). The variability in simulated ANPP also is within the range of $10-250 \mathrm{~g} \mathrm{~m}^{-2} \mathrm{y}^{-1}$ estimated by Lieth (1973) for desert scrub ecosystems and close to that of $30-200 \mathrm{~g} \mathrm{~m}^{-2} \mathrm{y}^{-1}$ estimated by Noy-Meir (1973) for arid ecosystems.
Our modeling results showed that the mean ANPP of the Larrea ecosystem was lower in northwestern Phoenix than in southeastern Arizona. This is consistent with observations. For example, Whittaker and Niering (1975) reported that the ANPP of a Larrea community near Tucson, Arizona was $92.0 \mathrm{~g} \mathrm{~m}^{-2} \mathrm{y}^{-1}$, while Chew and Chew's (1965) field measurements showed that the ANPP of the same plant community type, located $140 \mathrm{~km}$ away from Tucson, could reach $130 \mathrm{~g} \mathrm{~m}^{-2} \mathrm{y}^{-1}$. Furthermore, the simulations showed that $70.9 \%$ of the total ecosystem ANPP was contributed by Larrea, $10.9 \%$ by subshrub, $3.2 \%$ by perennial grasses, $8.1 \%$ by $\mathrm{C} 3$ annuals, $4.0 \%$ by forbs, and $2.9 \%$ by $\mathrm{C} 4$ annuals. These simulated results were similar to the measurements by Chew and Chew (1965), which showed that the relative ANPP contributions 

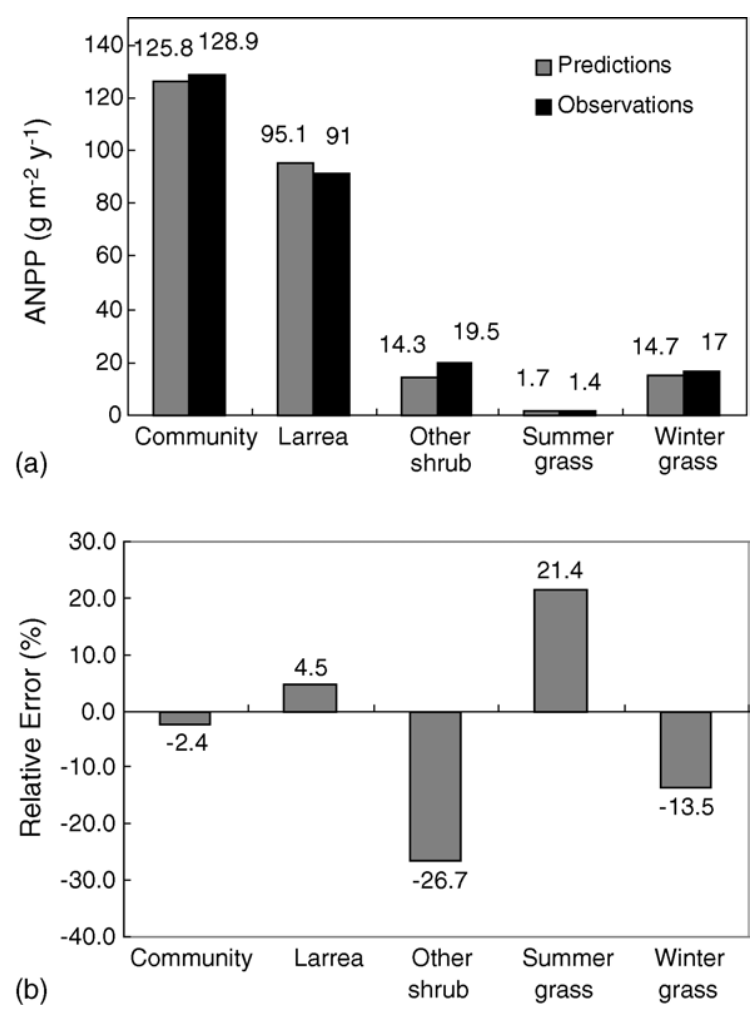

Fig. 5. Comparison of simulated aboveground net primary production (ANPP) with observed ANPP of different plant functional types of the Larrea ecosystem in the San Simon Valley, southeastern Arizona. Observed ANPP is from Table 7 in Chew and Chew (1965). Values are noted above each bar.

by different FTs were $69.5 \%$ for Larrea, $14.9 \%$ for other shrubs, $13.0 \%$ for fall crops, and about $1.1 \%$ for summer grasses (perennial grasses and forbs were not distinguished in their study).

\subsection{Seasonal and inter-annual pattern of NPP in response to precipitation fluctuations}

Water availability is the primary determinant of primary productivity in arid ecosystems around the world. Can the PALS-FT model accurately simulate the seasonal and inter-annual ANPP dynamics of the Sonoran Desert ecosystem in response to precipitation fluctuations? To address this question, we further analyze the responses of ANPP to precipitation changes based on our simulations at the Phoenix study area from 1988 to 2002 .
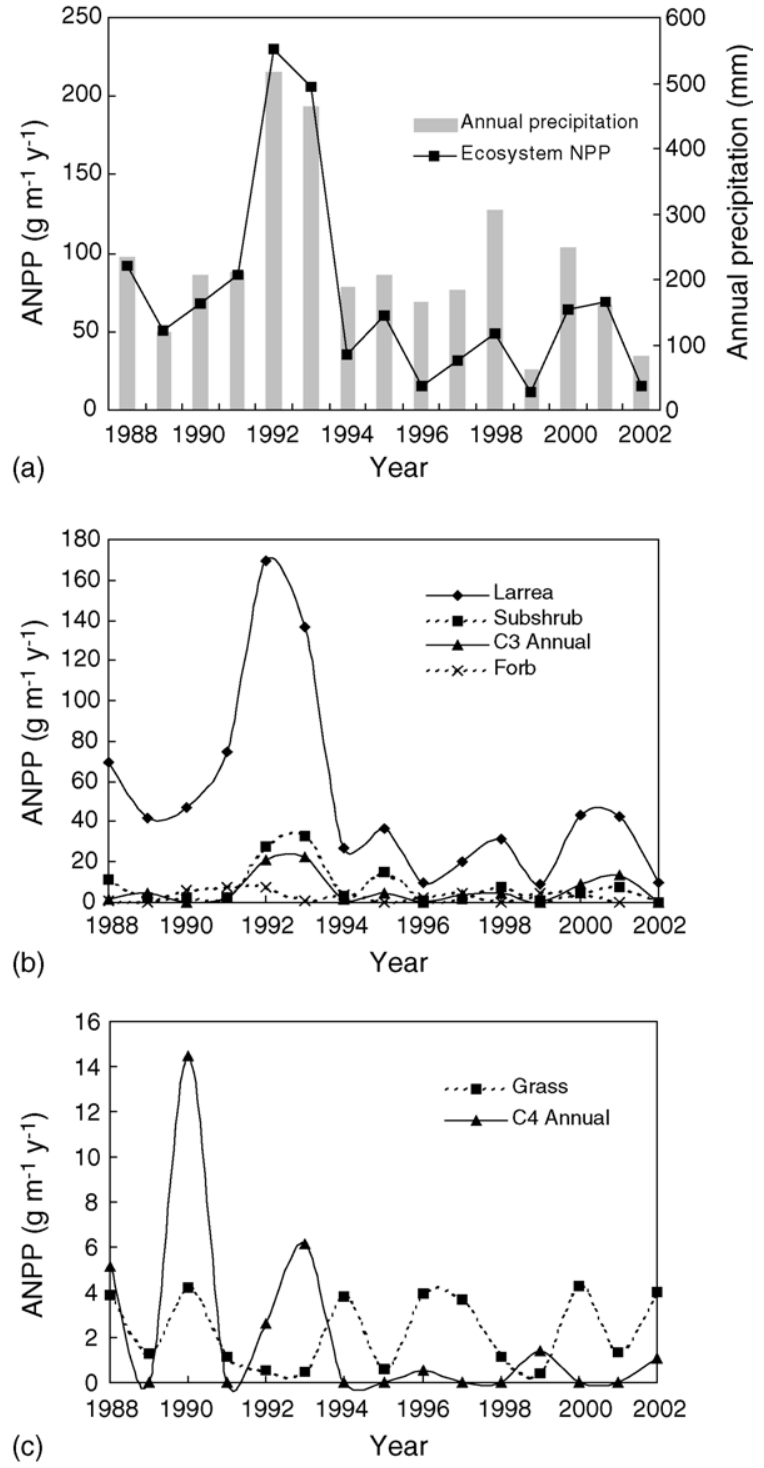

Fig. 6. Simulated decadal dynamics of ANPP of 6 plant functional types in the Larrea ecosystem of the Sonoran Desert Northwest of Phoenix.

Our simulation results showed that the dynamics of the ecosystem ANPP was closely related to variations in annual precipitation $\left(R^{2}=0.84\right.$; Fig. 6a). At the FT level, the ANPP of shrub, subshrub, C3 winter annual and forbs also was highly correlated with annual precipitation $\left(R^{2}=0.80,0.77,0.66\right.$, and 0.64 , respectively; Fig. 6b). In contrast, the ANPP of C4 summer annuals and perennial grass did not follow the pattern of 
rainfall $\left(R^{2}=0.11\right.$ and 0.06 , respectively; Fig. 6c). In spite of the general agreement between the two, for a particular year the relationship of ANPP with annual precipitation may not be strong. For example, while the annual precipitation in 2000 and 2001 was quite different (249.25 mm in 2000 versus $161.25 \mathrm{~mm}$ in 2001), the simulated ANPP for the two years was quite similar $\left(64.6 \mathrm{~g} / \mathrm{m}^{2}\right.$ in 2000 and $69.3 \mathrm{~g} / \mathrm{m}^{2}$ in 2001). The reason was that the leaf biomass within the ecosystem model decreased dramatically in 2000 because of the drought in 1999 with only $61 \mathrm{~mm}$ of rainfall. This phenomenon was also observed in the field (Bamberg et al., 1976).

How did the seasonal distribution of rainfall affect ANPP? Did the seasonal pattern of ANPP as predicted by PALS-FT agree with existing knowledge? To address these questions, we portioned annual precipitation into three parts as in Reynolds et al. (2004) (Fig. 7): spring rainfall (April 1-June 31), summer rainfall (July 1-September 31), and winter rainfall (October 1-March 31). Our analysis showed that ANPP of shrub, subshrub, C3 winter annual and forb were most closely related to winter rainfall $\left(R^{2}=0.68\right)$, whereas ANPP of $\mathrm{C} 4$ summer annual grass was most closely related to summer rainfall $\left(R^{2}=0.50\right)$. This general pattern was evident by visually comparing Figs. 7 and 8 . In contrast, ANPP of perennial grasses was not strongly correlated with either annual rainfall or rainfall associated with one particular season. Fig. 7 shows that most of the precipitation in the Sonoran Desert falls in winter. This seasonal distribution pattern favors the

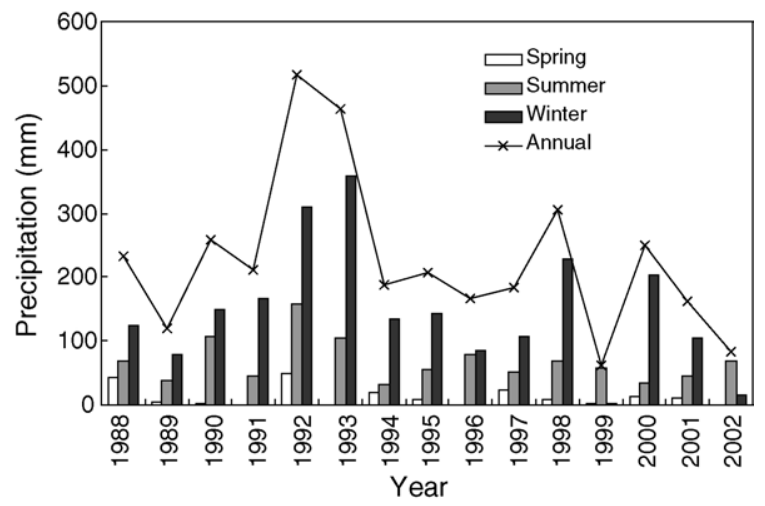

Fig. 7. Seasonal distribution and amount of rainfall in the 15 years from 1988 to 2002 in the Sonoran Desert of Northwestern Phoenix. The three seasons are defined as: spring (April 1-June 31), summer (June 30-September 30), and winter (October 1-March 31).
FTs of shrubs, subshrubs, C3 annuals and forbs whose growth occurs mostly in winter (Fig. 8). However, actual growth responses of $\mathrm{C} 4$ grasses may be somewhat different from the modeled responses since the model parameterization for $\mathrm{C} 4$ grass that was based on black grama (Bouteloua eriopoda), which is not the dominant $\mathrm{C} 4$ grass in the northwestern CAP-LTER study area. The $\mathrm{C} 4$ grasses of this region could have phenology patterns and growth responses that are substantially different from black grama.

\subsection{Comparison of simulated ANPP between PALS-FT and regression models}

Comparing the predictions by different models for same ecosystem may also provide confidence in the target model. For this reason, we chose two regression models from the literature that have been used to calculate ANPP of desert ecosystem; both developed for North American hot deserts. One is the Turner and Randall's (1989) model, which is a simple regression model that considers only annual precipitation as the determining variable of desert ANPP. The other is the Webb et al. (1983) model, which considers both abiotic factors (annual precipitation, annual potential evapotranspiration) and the current standing crop as primary determinants of Desert ANPP. The Turner and Randall's model has the form:

$\mathrm{ANPP}=0.30 \times \mathrm{ppt}-6.12$

where ppt is the annual rainfall in $\mathrm{mm}$. The Webb et al. model has the form:

$$
\begin{aligned}
\text { ANPP }= & 1.8 \times \text { FSC } \times \sum_{1}^{52} 2^{T_{i} / 10} \\
& \times \sinh \left(0.1 \times \max (0, \text { PPT }- \text { PET }) \times \Delta t_{i}\right)
\end{aligned}
$$

where FSC is the foliar standing crop $\left(\mathrm{g} / \mathrm{m}^{2}\right), T_{i}$ the weekly average temperature $\left({ }^{\circ} \mathrm{C}\right), \sin \mathrm{h}$ the hyperbolic sine function, PPT is weekly precipitation $(\mathrm{mm})$, PET is potential evapotranspiration $(\mathrm{mm}), \Delta t_{i}$ the fraction of a year. FSC was derived from Table A.3, $T_{i}$ and PPT was calculated from the weather data acquired from the San Simon Valley Weather Station. PET was calculated using the equations provided in Webb et al. (1983). 

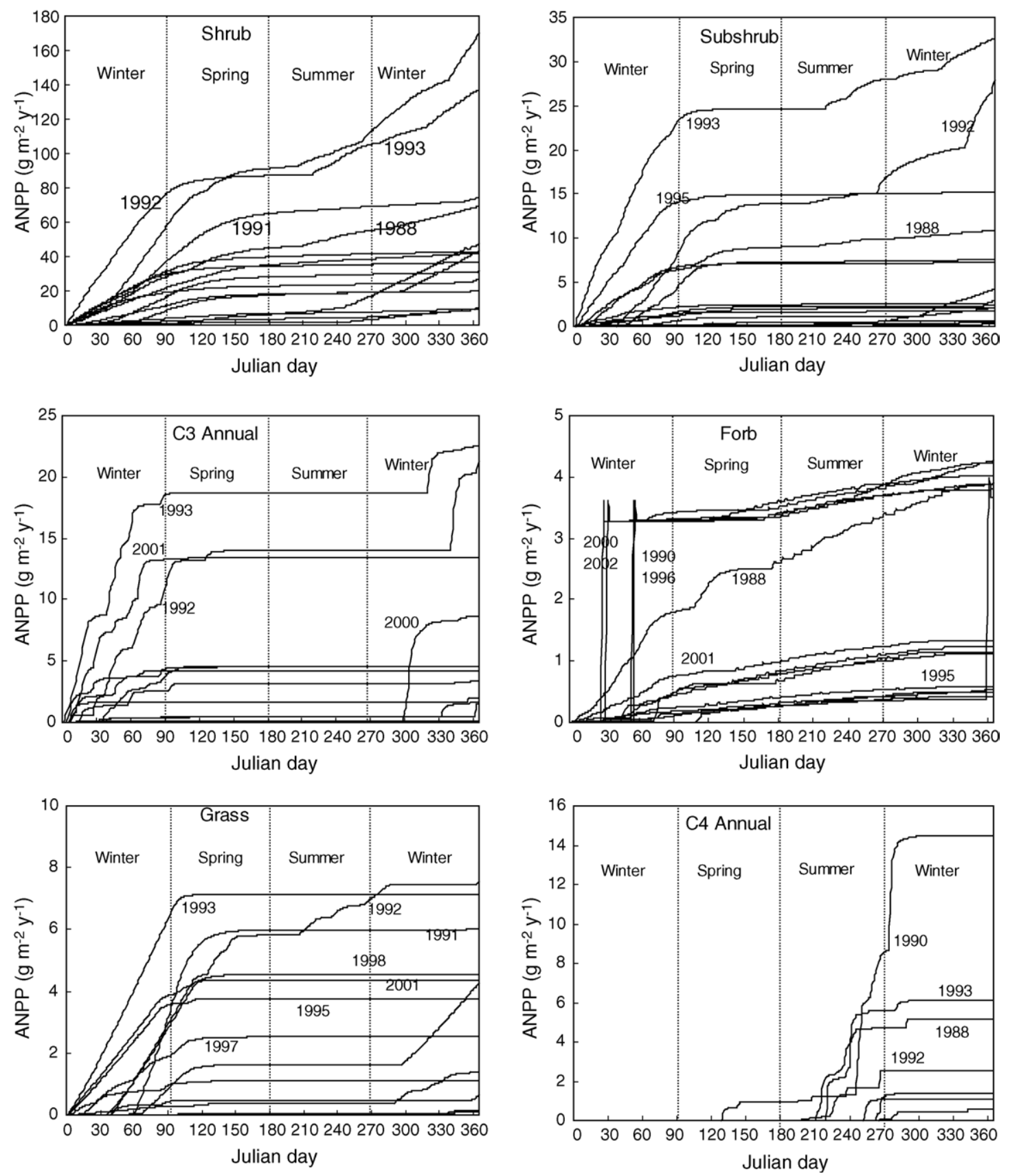

Fig. 8. Simulated seasonal variation in ANPP of different plant functional types over 15 years (1988-2002). Only those years with high rates of ANPP are shown; years having ANPP $=0$ are not plotted. 

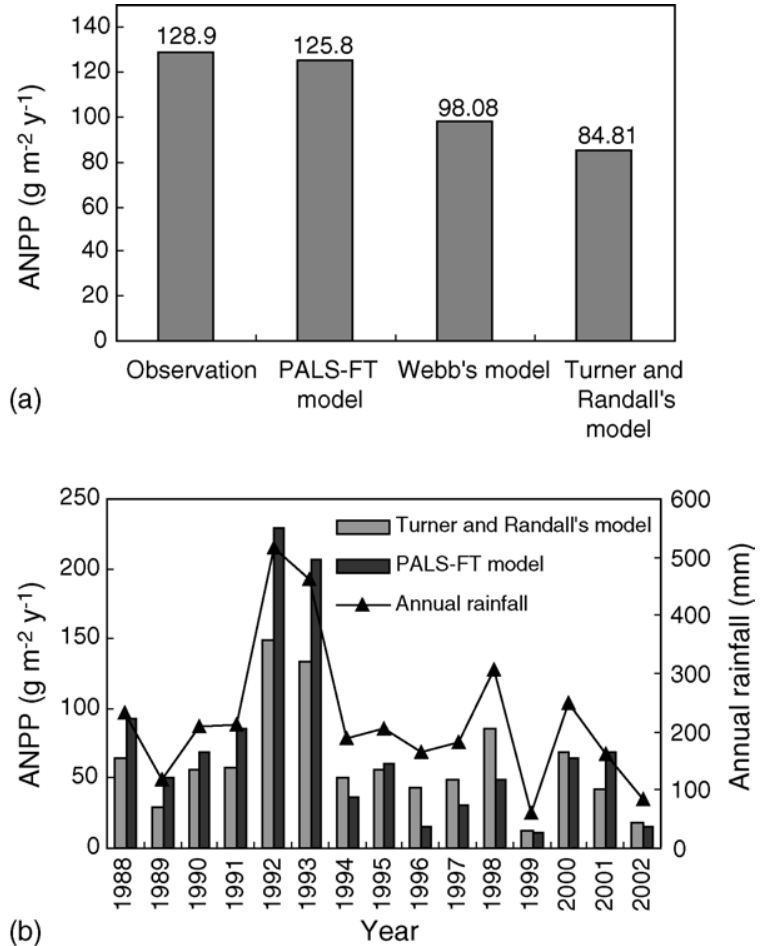

Fig. 9. Comparison of model predictions between PALS-FT and two regression models for the North American hot deserts. Panel a is for ANPP of the Larrea ecosystem in the San Simon Valley test site, and panel $b$ is for ANPP of the Larrea ecosystem in the CAP area.

The results of the regression models are presented in comparison with PALS-FT in Fig. 9. Both regression models underestimated the Larrea ecosystem ANPP of the San Simon Valley test site by $23.9 \%$ and $34.2 \%$, respectively, whereas the PALS-FT model provided an estimate that was closest to the observed ANPP (Fig. 9a). Comparing predictions of inter-annual variation in ANPP for the Larrea ecosystem in the CAP LTER study area, the Turner and Randall model prediction is more closely related to annual precipitation than the PALS-FT model prediction (Fig. 9b). However, the Turner and Randall model largely underestimates ANPP in wet years (e.g. 1992,1993) and overestimates ANPP in very dry years (e.g. 1996, 1999; Fig. 9b). We did not use the Webb's model to simulate the interannual ANPP variation because it requires an observed annual FSC value, which was unavailable for the CAP study area.

\section{Discussion and conclusions}

The results of this study showed that the PALSFT model, although originally developed for the Chihuahuan Desert, was able to simulate ANPP of the Larrea-dominated Sonoran Desert ecosystem reasonably well with only slight modifications. For the independent test site in the San Simon Valley, the relative error of the simulated ANPP was $\pm 2.4 \%$ at ecosystem level and generally less than $25 \%$ for individual FTs. Parton et al. (1993) claimed that a relative error of $\pm 25 \%$ should be acceptable for such simulations. The mean and variability of the simulated NPP for our Phoenix study area were also consistent with observations reported in the literature.

Simulated seasonal and inter-annual dynamics of ANPP also seemed reasonable for the Sonoran Desert ecosystem. At the ecosystem level, responses of simulated ANPP to fluctuations in annual precipitation confirmed the well documented general relationship between ANPP and precipitation in arid and semiarid systems, as well as the high variability in productivity with respect to variability in annual rainfall (LeHouerou et al., 1988). Further examination of the relationship for individual FTs revealed the importance of the seasonal distribution of rainfall to ANPP. In particular, winter rainfall was the better predictor of ANPP for most FTs in the Sonoran Desert ecosystem, except for $\mathrm{C} 4$ annuals, which are more responsive to summer rainfall. This suggests that, although the decadal pattern of ANPP can be adequately predicted by that of annual precipitation, information on the seasonal distribution of rain is needed for accurate predictions of the ecosystem ANPP for particular years.

Reynolds et al. (2004) conducted a comprehensive simulation analysis to explore how plants respond to variations in precipitation and soil water availability in the three North America warm deserts. They concluded that the "pulse-reserve" model, which relates ANPP linearly to annual precipitation (Noy-Meir, 1973; Turner and Randall, 1989; Whitford, 2002), is not adequate. The simulation results of Reynolds et al. (2004) showed that rainfall characteristics (e.g. seasonality and forms of rainfall) and soil water availability were also important to plant growth. In addition to rainfall and soil water availability, several other factors such as $\mathrm{N}$ availability, plant age, soil properties, and resource heterogeneity also can play a major role in 
determining ANPP (Whitford, 2002). Rainfall seasonality is a particularly important driving variable, as it accounts for much of the difference among the North American warm deserts and is likely to be sensitive to $\mathrm{CO}_{2}$-induced climate change (Grimm and Fisher, 1992; Grimm et al., 1997). The results of our study further support the notion that rainfall seasonality is crucial to plant growth in the Sonoran Desert.

The comparison of predictions of the PALS-FT model with those of two published regression models showed that the PALS-FT model was more accurate in predicting ANPP of the Larrea ecosystem. The underestimation of ANPP by the two regression models was likely due to the exclusion of other important variables that may be influential for predicting ANPP, such as precipitation seasonality and event duration, intensity of storm depth, time lapse since last rainfall, and seasonal temperatures (Whitford, 2002). Regression models have the advantage of fewer parameter requirements, but process-based models such as PALS-FT have more predictive and explanatory power, especially in investigating ecosystem responses to climatic and environmental changes. The PALS-FT model has a structure and includes functional relationships that are similar to some other models that have been employed for analyses in semi-arid grassland ecosystem, such as the CENTURY (Parton et al., 1988, 1993) and GRASS model (Coughenour et al., 1984). The PALS-FT model offers advantages over these models for use in arid shrublands with a diversity of plant FTs, since it has greater detail with respect to soil water dynamics and includes detailed growth and phenology processes of a variety of co-occurring and competing plant functional types that are likely to be found in communities of the hot deserts of southern Arizona.

The adaptation and validation of PALS-FT at the local ecosystem level within the Sonoran Desert is a critical, but only first, step toward achieving our long-term goal of understanding how Sonoran Desert ecosystems respond to changes in environmental conditions caused by urbanization and climate change (Wu and David, 2002). Testing model predictions against field observations and other model predictions is only part of the model evaluation process, and a good agreement between simulated and measured values alone does not guarantee the correctness of the model. To further employ the PALS-FT model in the diverse central Arizona Phoenix region, three challenges must be overcome. First, additional FTs (e.g. trees, agricultural crops) that characterize other land-use and land-cover types (e.g. residential urban area, agricultural land, and the upland subdivision of the Sonoran Desert (see Fig. 4) need to be incorporated into the model, or the FTs in the current version of the PALS-FT model need to be modified, reparameterized, and validated. Second, appropriate spatially explicit simulation approaches and scaling methods must be identified and used to link landscape pattern and ecosystem processes at multiple spatial scales (e.g. local ecosystem, landscape, and the whole CAP region), correspondingly, a multilayer spatial database needs to be developed for storing and updating pattern and process information at different scales. Third, variables that show large changes associated with urbanization or climate change- for example, rising temperature, elevated atmospheric $\mathrm{CO}_{2}$ concentration, and increasing $\mathrm{N}$ deposition- must be manipulated in simulation experiments to evaluate their effects. Our results confirm that such simulation experiments are likely to provide a strong and realistic set of predictions with which to compare actual longterm change in this rapidly urbanizing region. Thus, this study provides a basis for further investigating how urbanization-induced environmental changes influence the functional processes of the native Sonoran Desert ecosystem.

\section{Acknowledgements}

We would like to thank Corinna Gries and Diane Hope for their assistance with the 200-point survey data and comments on an earlier version of the manuscript, and Alaxander Buyantuyev for creating the map of the study area. This research was supported partly by U.S. EPA's STAR program (R827676-01-0 to JW), U.S. NSF (DEB 97-14833 and DEB-0423704 to CAP-LTER), and Natural Science Foundation of China (30100021 to WS and 30028002 to JW). PRK and JFR acknowledge NSF-DEB-02-12123 and USDA Specific Cooperative Agreement 58-12703-070 for support of the development of PALS-FT. WS also acknowledges support from Natural Science Foundation of Guangdong Province (010551) and Heshan Open Foundation. Two anonymous reviewers and Dr. Kerry Fowler made valuable comments on the manuscript. 


\section{Appendix A}

The PALS-FT model input parameters and their values used in this study (see Tables A.1-A.3).

Table A.1

Site characteristic parameters and their values

\begin{tabular}{|c|c|c|c|c|}
\hline Parameter & Description & Unit & Value & Source \\
\hline \multicolumn{5}{|c|}{ Soil physical and climate parameters } \\
\hline $\mathrm{ST}_{i=1-2}$ & Soil thickness of layer $1-2$ & $\mathrm{~cm}$ & 10 & 200-point survey \\
\hline $\mathrm{ST}_{i=3-6}$ & Soil thickness of layer 3-6 & $\mathrm{cm}$ & 20 & 200-point survey \\
\hline Clay $_{i=1-3}$ & Soil clay content (layer $1-3$ ) & $\%$ & 12.6 & 200-point survey \\
\hline Clay $_{i=4-6}$ & Soil clay content (layer 4-6) & $\%$ & 12 & 200-point survey \\
\hline Silt & Soil silt content (layer 1-6) & $\%$ & 51.3 & 200-point survey \\
\hline Sand & Soil sand content (layer 1-6) & $\%$ & 36.1 & 200-point survey \\
\hline $\operatorname{VWC}_{i=1,4-6}$ & Volumetric water content at soil layer 1 and layer 4-6 & $\%$ & 7.5 & 200-point survey \\
\hline $\operatorname{VWC}_{i=2-3}$ & Volumetric soil water content at layer $2-3$ & $\%$ & 11 & 200-point survey \\
\hline $\mathrm{FC}$ & Field capacity & bar & 0.25 & 200-point survey \\
\hline Ppt & Daily precipitation & $\mathrm{mm}$ & $1988-2002$ & AZMET $^{1}$ \\
\hline$T_{\max }$ & Daily Maximum air temperature & ${ }^{\circ} \mathrm{C}$ & 1988-2002 & AZMET \\
\hline$T_{\min }$ & Daily Minimum air temperature & ${ }^{\circ} \mathrm{C}$ & $1988-2002$ & AZMET \\
\hline $\mathrm{RH}$ & Daily Relative humidity & $\%$ & 1988-2002 & AZMET \\
\hline $\mathrm{Sr}$ & Daily Solar radiation & MJ & $1988-2002$ & AZMET \\
\hline $\mathrm{C}_{\mathrm{a}}$ & Partial pressure of Atmospheric $\mathrm{CO}_{2}$ & $\mathrm{kPa}$ & 0.036 & AZMET \\
\hline \multicolumn{5}{|c|}{ Plant biomass parameters } \\
\hline $\mathrm{AGB}_{\mathrm{wnt}}$ & Aboveground biomass of $\mathrm{C} 3$ grasses & $\mathrm{g} \mathrm{DM} \mathrm{m}^{-2}$ & 0.2 & 200-point survey \\
\hline $\mathrm{AGB}_{\mathrm{smr}}$ & Aboveground biomass of $\mathrm{C} 4$ grasses & $\mathrm{g} \mathrm{DM} \mathrm{m}^{-2}$ & 0 & 200-point survey \\
\hline $\mathrm{AGB}_{\text {forb }}$ & Aboveground biomass of forbs & $\mathrm{g} \mathrm{DM} \mathrm{m}^{-2}$ & 0.2 & 200-point survey \\
\hline$B_{\text {lvs,prn }}$ & Leaf biomass of perennial grasses & $\mathrm{g} \mathrm{DM} \mathrm{m}^{-2}$ & 7.9 & 200-point survey \\
\hline $\mathrm{DB}_{\text {lvs }}$,prn & Dead leaf biomass of perennial grasses & $\mathrm{g} \mathrm{DM} \mathrm{m}^{-2}$ & 10.5 & 200-point survey \\
\hline $\mathrm{B}_{\mathrm{rts}, \mathrm{prn}}$ & Root biomass of perennial grasses & $\mathrm{g} \mathrm{DM} \mathrm{m}^{-2}$ & 13.2 & 200-point survey \\
\hline $\mathrm{DB}_{\mathrm{rts}, \mathrm{prn}}$ & Dead root biomass of perennial grasses & $\mathrm{g} \mathrm{DM} \mathrm{m}^{-2}$ & 26.4 & 200-point survey \\
\hline $\mathrm{B}_{\text {lvs,shrb }}$ & Leaf biomass of shrub & $\mathrm{g} \mathrm{DM} \mathrm{m}^{-2}$ & 50.4 & 200-point survey \\
\hline $\mathrm{DB}_{\text {lvs,shrb }}$ & Dead leaf biomass of shrub & $\mathrm{g} \mathrm{DM} \mathrm{m}^{-2}$ & 10.1 & 200-point survey \\
\hline $\mathrm{B}_{\mathrm{stm}, \mathrm{shrb}}$ & Stem biomass of shrub & $\mathrm{g} \mathrm{DM} \mathrm{m}^{-2}$ & 158.8 & 200-point survey \\
\hline $\mathrm{DB}_{\mathrm{stm}, \mathrm{shrb}}$ & Dead stems of shrub & $\mathrm{g} \mathrm{DM} \mathrm{m}^{-2}$ & 31.8 & 200-point survey \\
\hline $\mathrm{B}_{\mathrm{rts}, \mathrm{shrb}}$ & Root biomass of shrub & $\mathrm{g} \mathrm{DM} \mathrm{m}^{-2}$ & 70.6 & 200-point survey \\
\hline $\mathrm{DB}_{\mathrm{rts}, \mathrm{shrb}}$ & Dead root of shrub & $\mathrm{g} \mathrm{DM} \mathrm{m}^{-2}$ & 14.1 & 200-point survey \\
\hline $\mathrm{B}_{\mathrm{lvs}, \mathrm{ss}}$ & Subshrub leaf biomass & $\mathrm{g} \mathrm{DM} \mathrm{m}^{-2}$ & 14.8 & 200-point survey \\
\hline $\mathrm{DB}_{\text {lvs }, \mathrm{ss}}$ & Subshrub dead leaf biomass & $\mathrm{g} \mathrm{DM} \mathrm{m}^{-2}$ & 1.5 & 200-point survey \\
\hline $\mathrm{B}_{\mathrm{stm}, \mathrm{ss}}$ & Subshrub stem biomass & $\mathrm{g} \mathrm{DM} \mathrm{m}^{-2}$ & 43.4 & 200-point survey \\
\hline $\mathrm{DB}_{\mathrm{stm}, \mathrm{ss}}$ & Subshrub dead stem biomass & $\mathrm{g} \mathrm{DM} \mathrm{m}^{-2}$ & 21.7 & 200-point survey \\
\hline $\mathrm{B}_{\mathrm{rts}, \mathrm{ss}}$ & Subshrub root biomass & $\mathrm{g} \mathrm{DM} \mathrm{m}^{-2}$ & 20.5 & 200-point survey \\
\hline $\mathrm{DB}_{\mathrm{rts}, \mathrm{ss}}$ & Subshrub dead root biomass & $\mathrm{g} \mathrm{DM} \mathrm{m}^{-2}$ & 4.1 & 200-point survey \\
\hline \multicolumn{5}{|c|}{ Plant litter and soil organic matter parameters } \\
\hline $\mathrm{L}_{\text {met,lvs }}$ & Leaf litter metabolic C & $\mathrm{gC} \mathrm{m}^{-2}$ & 2.5 & 200-point survey \\
\hline $\mathrm{L}_{\text {str,lvs }}$ & Leaf litter structural C & $\mathrm{gC} \mathrm{m}^{-2}$ & 18.8 & 200-point survey \\
\hline $\mathrm{L}_{\text {met,rts }}$ & Root litter metabolic C & $\mathrm{gC} \mathrm{m}^{-2}$ & 2.0 & 200-point survey \\
\hline $\mathrm{L}_{\mathrm{str}, \mathrm{rts}}$ & Root litter structural C & $\mathrm{gC} \mathrm{m}^{-2}$ & 6.0 & 200-point survey \\
\hline $\mathrm{L}_{\text {met,stm }}$ & Stem litter metabolic C & $\mathrm{gC} \mathrm{m}^{-2}$ & 0.5 & 200-point survey \\
\hline $\mathrm{L}_{\mathrm{str}, \mathrm{stm}}$ & Stem Litter structural C & $\mathrm{gC} \mathrm{m}^{-2}$ & 1.5 & 200-point survey \\
\hline $\mathrm{AOM}_{\mathrm{lvs}}$ & Leaf active OM & $\mathrm{gC} \mathrm{m}^{-2}$ & 12.5 & 200-point survey \\
\hline $\mathrm{AOM}_{\mathrm{rts}}$ & Root active OM & $\mathrm{gC} \mathrm{m}^{-2}$ & 13.5 & 200-point survey \\
\hline $\mathrm{SOM}_{\mathrm{rts}}$ & Root slow OM & $\mathrm{gC} \mathrm{m}^{-2}$ & 725 & 200-point survey \\
\hline
\end{tabular}


Table A.1 (Continued)

\begin{tabular}{lllll}
\hline Parameter & Description & Unit & Value & Source \\
\hline POM $_{\mathrm{rts}}$ & Root passive OM & $\mathrm{g} \mathrm{C} \mathrm{m}^{-2}$ & 862 & 200-point survey \\
$\mathrm{N}_{\text {soil }}$ & Soil nitrogen content & $\mathrm{g} \mathrm{N} \mathrm{m}^{-2}$ & 5.74 & 200 -point survey \\
$\mathrm{K}_{\text {met,lvs }}$ & Metabolic leaf litter decomposition rate & fraction & 0.05 & Kemp et al., 2003 \\
$\mathrm{K}_{\text {met,rts }}$ & Metabolic root litter decomposition rate & fraction & 0.05 & Kemp et al., 2003 \\
$\mathrm{K}_{\text {met,stm }}$ & Metabolic stem litter decomposition rate & Fraction & 0.003 & Moorhead and Reynolds, 1989 \\
$\mathrm{K}_{\mathrm{AOM}, \text { lvs }}$ & Leaf Active organic matter decomposition rate & Fraction & 0.0016 & Kemp et al., 2003 \\
$\mathrm{K}_{\mathrm{AOM}, \mathrm{rts}}$ & Root active organic matter decomposition rate & fraction & 0.0016 & Kemp et al., 2003 \\
$\mathrm{K}_{\mathrm{SOM}, \mathrm{rts}}$ & Root slow organic matter decomposition rate & fraction & 0.00054 & Kemp et al., 2003 \\
$\mathrm{K}_{\text {POM,rts }}$ & Root passive organic matter decomposition rate & Fraction & 0.000019 & Kemp et al., 2003 \\
\hline
\end{tabular}


Table A.2

Ecophysiological input parameters and their values used in the PALS-FT model

\begin{tabular}{|c|c|c|c|c|c|c|c|c|c|}
\hline \multirow[t]{2}{*}{ Parameter } & \multirow[t]{2}{*}{ Description } & \multicolumn{6}{|l|}{ Value } & & \multirow[t]{2}{*}{ Source } \\
\hline & & Unit & Shrub (Larrea) & Subshrub & Perennial grass & Forb & C3 annuals & C4 annuals & \\
\hline \multirow[t]{6}{*}{$\mathrm{RF}_{i=1-6}$} & \multirow[t]{2}{*}{ Root distribution fraction $0-10 \mathrm{~cm}$} & \multirow[t]{6}{*}{ Fraction } & 0.1 & 0.1 & 0.2 & 0.2 & 0.3 & 0.4 & $\begin{array}{l}\text { Kemp et al., 1997; } \\
\text { Thames, } 1979\end{array}$ \\
\hline & & & 0.19 & 0.2 & 0.3 & 0.2 & 0.4 & 0.4 & Forseth et al., 1984 \\
\hline & $10-20 \mathrm{~cm}$ & & 0.48 & 0.25 & 0.25 & 0.3 & 0.25 & 0.2 & Reynolds et al., 2004 \\
\hline & $20-40 \mathrm{~cm}$ & & 0.15 & 0.25 & 0.15 & 0.2 & 0.05 & 0 & \\
\hline & $40-60 \mathrm{~cm}$ & & 0.05 & 0.2 & 0.10 & 0.1 & 0 & 0 & \\
\hline & $60-80 \mathrm{~cm}$ & & 0.02 & 0 & 0 & 0 & 0 & 0 & \\
\hline SLA & Specific leaf area, & $\mathrm{m}^{2} \mathrm{~g}^{-1}$ & 0.006 & 0.011 & 0.015 & 0.015 & 0.015 & 0.015 & Werk et al., 1983 \\
\hline Phi & Respiratory loss per day & Fraction & 0.45 & 0.40 & 0.35 & 0.25 & 0.25 & 0.25 & Reynolds et al., 2000 \\
\hline$a$ & Parameter in Eq. 14 & Dimensionless & 0.52 & 0.566 & 0.75 & 1.0 & 1.0 & 0.75 & Reynolds et al., 2000 \\
\hline$b$ & Parameter in Eq. 14 & Dimensionless & -0.06 & -0.125 & -0.15 & -0.18 & -0.20 & -0.25 & Reynolds et al., 2000 \\
\hline$C_{\min , i}$ & Partial pressure of intercellular $\mathrm{CO}_{2}$ & $\mathrm{kPa}$ & 0.023 & 0.025 & 0.016 & 0.025 & 0.025 & 0.015 & $\begin{array}{l}\text { Forseth and } \\
\text { Ehleringer, 1983; } \\
\text { Werk et al., } 1984\end{array}$ \\
\hline$R_{\mathrm{lvs}}$ & Ratio of production of leaves & Fraction & 0.4 & 0.4 & 0.95 & 1.0 & 1.0 & 1.0 & Reynolds et al., 2000 \\
\hline$R_{\mathrm{rts}}$ & Ratio of production of roots & Fraction & 0.3 & 0.25 & 0.05 & 0.2 & 0.25 & 0.3 & Reynolds et al., 2000 \\
\hline$N_{\min }$ & Minimum $\mathrm{N}$ content in leaf, & $\%$ & 0.8 & 0.8 & 0.75 & 1.0 & 1.0 & 1.0 & $\begin{array}{l}\text { Lajtha and Whitford, } \\
1989\end{array}$ \\
\hline$N_{\text {stem }}$ & $\mathrm{N}$ content in stem & $\%$ & 2.4 & 1.5 & - & - & - & - & Kemp et al., 2003 \\
\hline$N_{\text {root }}$ & $\mathrm{N}$ content in root & $\%$ & 2.4 & 2.5 & 1.0 & 2.0 & 2.0 & 2.0 & Kemp et al., 2003 \\
\hline$F_{\text {lab,min }}$ & $\begin{array}{l}\text { Fraction of } \mathrm{N} \text { in labile material lost } \\
\text { due to microbial respiration; }\end{array}$ & Fraction & & & & & 0.55 & & Reynolds et al., 2000 \\
\hline$F_{\text {lig,min }}$ & $\begin{array}{l}\text { Fraction of } \mathrm{N} \text { in non-labile material } \\
\text { (lignin and cellulose) lost due to } \\
\text { microbial respiration }\end{array}$ & Fraction & & & & & 0.30 & & Reynolds et al., 2000 \\
\hline$N_{\mathrm{lvs}}$ & Nitrogen content in litter & $\%$ & & & & & 2.4 & & Kemp et al., 2003 \\
\hline$C_{\text {plant }}$ & Carbon content in plant & Fraction & & & & & 0.52 & & Kemp et al., 2003 \\
\hline $\mathrm{LG}_{\mathrm{lvs}}$ & Lignin content in leaf litter & Fraction & & & & & 0.10 & & Kemp et al., 2003 \\
\hline $\mathrm{CL}_{\mathrm{lvs}}$ & Cellulose content in leaf litter & Fraction & & & & & 0.65 & & Kemp et al., 2003 \\
\hline $\mathrm{LG}_{\mathrm{stm}}$ & Lignin content in stem litter & Fraction & & & & & 0.22 & & Kemp et al., 2003 \\
\hline $\mathrm{CL}_{\mathrm{stm}}$ & Cellulos content in stem litter & Fraction & & & & & 0.53 & & Kemp et al., 2003 \\
\hline $\mathrm{LG}_{\mathrm{rts}}$ & Lignin content in root litter & Fraction & & & & & 0.22 & & Kemp et al., 2003 \\
\hline $\mathrm{CL}_{\mathrm{rts}}$ & Cellulose content in root litter & Fraction & & & & & 0.53 & & Kemp et al., 2003 \\
\hline
\end{tabular}


Table A.3

List of major input parameters for the test site in San Simon Valley

\begin{tabular}{|c|c|c|c|c|c|c|}
\hline Input parameters & Unit & Shrub (Larrea) & Other shrub & Perennial grass & Forb & Annual grass (mainly C3) \\
\hline \multicolumn{7}{|l|}{ For different plant functional types } \\
\hline Live leaf biomass & $\mathrm{g} \mathrm{DM} \mathrm{m}^{-2}$ & 49.18 & 6.8 & 0.48 & 0.2 & 0.1 \\
\hline Dead leaf biomass & $\mathrm{g} \mathrm{DM} \mathrm{m}^{-2}$ & 9.84 & 0.64 & 0.64 & 0 & 0 \\
\hline Live stem biomass & $\mathrm{g} \mathrm{DM} \mathrm{m}^{-2}$ & 320.3 & 7.20 & 0 & 0 & 0 \\
\hline Dead stem biomass & $\mathrm{g} \mathrm{DM} \mathrm{m}^{-2}$ & 64.05 & 3.60 & 0 & 0 & 0 \\
\hline Live root biomass & $\mathrm{g} \mathrm{DM} \mathrm{m}^{-2}$ & 96.99 & 10.5 & 0.8 & 0 & 0 \\
\hline Dead root biomass & $\mathrm{g} \mathrm{DM} \mathrm{m}^{-2}$ & 19.4 & 2.1 & 0.16 & 0 & 0 \\
\hline Root distribution (in three layers) & Fraction & $0.1,0.5,0.4$ & $0.3,0.5,0.2$ & $0.5,0.4,0.1$ & $0.4,0.5,0.1$ & $0.6,0.4,0.0$ \\
\hline \multicolumn{7}{|l|}{ For the whole ecosystem } \\
\hline Metabolic leaf litter & $\mathrm{g} \mathrm{C} \mathrm{m}^{-2}$ & 4.3 & & & & \\
\hline Structural leaf litter & $\mathrm{gC} \mathrm{m}^{-2}$ & 32.3 & & & & \\
\hline Metabolic stem litter & $\mathrm{gC} \mathrm{m}^{-2}$ & 0.9 & & & & \\
\hline Structural stem litter & $\mathrm{gC} \mathrm{m}^{-2}$ & 2.7 & & & & \\
\hline Metabolic root litter & $\mathrm{gC} \mathrm{m}^{-2}$ & 3.5 & & & & \\
\hline Structural root litter & $\mathrm{gC} \mathrm{m}^{-2}$ & 10.5 & & & & \\
\hline Surface active organic matter & $\mathrm{gC} \mathrm{m}^{-2}$ & 2.4 & & & & \\
\hline Active soil organic matter & $\mathrm{gC} \mathrm{m}^{-2}$ & 78.6 & & & & \\
\hline Slow soil organic matter & $\mathrm{gC} \mathrm{m}^{-2}$ & 1152 & & & & \\
\hline Passive soil organic matter & $\mathrm{gC} \mathrm{m}^{-2}$ & 1378 & & & & \\
\hline
\end{tabular}

Biomass of Larrea was derived from mean standing weight of individuals (g dry matter per plant) from Chew and Chew (1965). Biomass of other FTs was estimated based on the cover values of different FTs in Chew and Chew (1965) and the cover-biomass relations listed in Table 1. Methods for determining dead biomass, biomass allocation ratios, root distribution fractions, litter and soil organic matter pools are described in text.

\section{References}

Ball, J.T., Woodrow, I.E., Berry, J.A., 1987. A model predicting stomatal conductance and its contribution to the control of photosynthesis under different environmental conditions. In: Biggens, J. (Ed.), Progress in Photosynthesis Research. Martinus-Nijhoff, Dordrecht, The Netherlands, pp. 221-224.

Bamberg, S.A., Vollmer, A.T., Kleinkopf, G.E., Ackerman, T.L., 1976. A comparison of seasonal primary production of Mojave Desert shrubs during wet and dry years. Am. Midland Naturalist 95, 398-405.

Bell, K.L., Hiatt, H.D., Niles, W.E., 1979. Seasonal changes in biomass allocation in eight winter annuals of the Mojave Desert. J. Ecol. 67, 781-787.

Brown, D.E. (Ed.), 1994. Biotic Communities: Southwestern United States and Northwestern Mexico. University of Utah Press, Salt Lake City, Utah.

Burk, J., Dick-Peddie, W.A., 1973. Comparative production of Larrea divaricata Cav. on three geomorphic surfaces in southern New Mexico. Ecology 54, 1094-1102.

Caldwell, M.M., Camp, L.B., 1974. Belowground productivity of two cool desert communities. Oecologia 17, 123-130.

Camp, P.D., 1986. Soil survey of Aguila-Carefree area, parts of Maricopa and Pinal Counties, Arizona. United States Department of Agriculture, Soil Conservation Service, In cooperation with United Statess Department of the Interior, Bureau of Indian Affairs and Bureau of Land Management, and the Arizona Agricultural Experiment Station.
Campbell, G.S., 1977. An Introduction to Environmental Biophysics, 2nd ed. Springer-Verlag, New York.

Chew, R.M., Chew, A.E., 1965. The primary productivity of a desert shrub (Larrea tridentata) community. Ecol. Monographs 35, 335-375.

Coughenour, M.B., McNaughton, S.J., Wallace, L.L., 1984. Modelling primary production of perennial graminoids: uniting physiological processes and morphometric traits. Ecol. Modelling 23, 101-134.

Ehleringer, J., 1983. Ecophysiology of Amaranthus palmeri, a Sonoran Desert summer annual. Oecologia 57, 107-112.

Fischer, R.A., Turner, N.C., 1978. Plant productivity in the arid and semiarid zones. Ann. Rev. Plant Physiol. 29, 277-317.

Fisher, F.M., Zak, J.C., Cunningham, G.L., Whitford, W.G., 1988. Water and nitrogen effects on growth and allocation patterns of creosotebush in the northern Chihuahuan Desert. J. Range Manage. 41, 387-390.

Forseth, I.N., Ehleringer, J., 1983. Ecophysiology of two solar tracking desert winter annuals. III. Gas exchange responses to light, $\mathrm{CO}_{2}$ and VPD in relation to long-term drought. Oecologia 57, 340-351.

Forseth, I.N., Ehleringer, J.R., Werk, K.S., Cook, C.S., 1984. Field water relations of Sonoran Desert annuals. Ecology 65, 1436-1444.

Gao, Q., Reynolds, J.F., 2003. Historical shrub-grass transitions in the northern Chihuahuan Desert: modeling the effects of shifting rainfall seasonality and event size over a landscape gradient. Global Change Biol. 9, 1475-1493. 
Grimm, N.B., Grove, J.M., Redman, C.L., Pickett, S.T.A., 2000. Integrated approaches to long-term studies of urban ecological systems. BioScience 50, 571-584.

Grimm, N.B., Fisher, S.G., 1992. Responses of arid land streams to changing climate. In: Firth, P., Fisher, S.G. (Eds.), Climate Change and Freshwater Ecosystems. Springer-Verlag, New York.

Grimm, N.B., Chacón, A., Dahm, C.N., Lind, O.T., Starkweather, P.L., Wurtsbaugh, W.W., 1997. Sensitivity of aquatic ecosystems to climatic and anthropogenic changes: the Basin and Range, American Southwest, and México. Hydrol. Process. 11, 1023-1041.

Hadley, N.F., Szarek, S.R., 1981. Productivity of desert ecosystems. BioScience 31, 747-753.

Hope, D., Gries, C., Zhu, W., Fagan, W.F., Redman, C.L., Grimm, N.B., Nelson, A.L., Martin, C., Kinzig, A., 2003. Socioeconomics drive urban plant diversity. Proc. Nat. Acad. Sci. 100, 8788-8792.

Jarvis, P.G., 1976. The interpretation of the variations in leaf water potential and stomatal conductance found in canopies in the field. Philosophical transactions of the Royal Society of London Series B. Biol. Sci. 273, 593-610.

Johnson, H.B., Vasek, F.C., Yonkers, T., 1978. Residual effects of summer irrigation on Mojave Desert annuals. Bull. California Acad. Sci. 77, 95-108.

Jorgensen, S.E., 1986. Fundamentals of Ecological Modelling. Elsevier, Amsterdam, The Netherlands.

Kemp, P.R., Reynolds, J.F., Packepsky, Y., Chen, J.-L., 1997. A comparative modeling study of soil water dynamics in a desert ecosystem. Water Resources Res. 33, 73-90.

Kemp, P.R., Reynolds, J.F., Virginia, R.A., Whitford, W.G., 2003. Decomposition of leaf and root litter of Chihuahuan desert shrubs; effects of three years of summer drought. J. Arid Environ. 53, 21-39.

Kenneth,D.V., 1980. Soil survey of San Simon area, Arizona, parts of Cochise, Graham, and Greenlee Counties. United States Department of Agriculture, Soil Conservation Service in cooperation with Arizona Agricultural Experiment Station.

Lajtha, K., Whitford, W.G., 1989. The effect of water and nitrogen amendments on photosynthesis, leaf demography, and resourceuse efficiency in Larrea tridentata, a desert evergreen shrub. Oecologia 80, 341-348.

LeHouerou, H.N., Bingham, R.L., Skerbek, W., 1988. Relationship between the variability of primary production and the variability of annual precipitation in world arid lands. J. Arid Environ. 15, $1-18$.

Leuning, R., 1995. A critical appraisal of a combined stomatalphotosynthesis model for C3 plants. Plant Cell Environ. 18, 339-355.

Lieth, H., 1973. Primary production: terrestrial ecosystems. Human Ecol. 1, 303-332.

Ludwig, J.A., 1986. Primary production variability in desert ecosystems. In: Whitford, W.G. (Ed.), Pattern and Process in Desert Ecosystems. University of New Mexico Press, Albuquerque, New Mexico, USA, pp. 5-17.

Ludwig, J.A., 1987. Primary productivity in arid lands: myths and realities. J. Arid Environ. 13, 1-7.
MacMahon, J.A., 2000. Warm deserts. In: Barbour, M.G., Billings, W.D. (Eds.), North American Terrestrial Vegetation. Cambridge University Press, Cambridge, UK, pp. 285-322.

Monteith, J.L., Unsworth, M.H., 1990. Principles of Environmental Physics, 2nd ed. Edward Arnold, New York.

Moorhead, D.L., Reynolds, J.F., 1989. The contribution of abiotic processes to buried litter decomposition in the northern Chihuahuan Desert. Oecologia 79, 133-135.

Noy-Meir, I., 1973. Desert ecosystems: environment and producers. Ann. Rev. Ecol. Systematics 4, 25-51.

Oren, R., Sperry, J.S., Katul, G.G., Pataki, D.E.,Ewers, B.E., Phillips, N., Schäfer, K.V.R., 1999. Survey and synthesis of intra- and interspecific variation in stomatal sensitivity to vapor pressure deficit. Plant Cell Environ. 22, 1515-1526.

Parton, W.J., Stewart, W.B., Cole, C.V., 1988. Dynamics of C, N, P and $\mathrm{S}$ in grassland soils: a model. Biogeochemistry 5, 109-131.

Parton, W.J., Scurlock, J.M.O., Ojima, D.S., Gilmanov, T.G., Scholes, R.J., Schimel, D.S., Kirchner, T., Menaut, J.-C., Seastedt, T., Garcia Moya, E., Kamnalrut, A., Kinyamario, J.I., 1993. Observations and modeling of biomass and soil organic matter dynamics for the grassland biome worldwide. Global Biogeochem. Cycles 7, 785-809.

Parton, W.J., Coughenour, M.B., Scurlock, M.O., Ojima, D.S., Gilmanov, T.G., Scholes, R.J., Schimel, D.S., Kirchner, T.B., Menaut, J.-C., Seastedt, T.R., Moya, E.G., Kamnalrut, A., Kinyamario, J.I., Hall, D.O., 1996. Global grassland ecosystem modeling: development and test of ecosystem models for grassland systems. In: Breymeyer, A.T., Hall, D.O., Mellillo, J.M., Agren, G.I. (Eds.), SCOPE 56: Global Change Effects on Coniferous Forests and Grasslands. John Wiley \& Sons, New York, pp. 229-268.

Parton, B., Ojima, D.S., Grossoand, S.D., Keough, C., 2001. CENTURY tutorial: supplement to CENTURY user's manual. Great Plains System Research Unit Technical Reprot no. 4, US-DAARS, Fort Collins, Colorado, USA.

Reynolds, J.F., Cunningham, G.L., 1981. Validation of a primary production model of the desert shrub Larrea tridentata using soilmoisture augmentation experiments. Oecologia 51, 357-363.

Reynolds, J.F., Hilbert, D.W., Kemp, P.R., 1993. Scaling ecophysiology from the plant to the ecosystem: A conceptual framework. In: Ehleringer, J.E., Field, C.B. (Eds.), Scaling Physiological Process. Academic Press, San Diego, pp. 127-140.

Reynolds, J.F., Kemp, P.R., Ogle, K., Fernandez, R.J., 2004. Precipitation pulses, soil water and plant responses: modifying the 'pulse-reserve' paradigm for deserts of North America. Oecologia 141, 194-210.

Reynolds, J.F., Kemp, P.R., Tenhunen, J.D., 2000. Effects of longterm rainfall variability on evapotranspiration and soil water distribution in the Chihuahuan Desert: a modeling analysis. Plant Ecol. 150, 145-159.

Reynolds, J.F., Smith, D.M.S. (Eds.), 2002. Global Desertification: Do Humans Cause Deserts?. Dahlem University Press, Berlin.

Reynolds, J.F., Strain, B.R., Cunningham, G.L., Knoerr, K.R., 1980. Predicting primary production for forest and desert ecosystem models. In: Hesketh, J.D., Jones, J.W. (Eds.), Predicting Photosynthesis for Ecosystem Models. CRC Press, Boca Raton, Florida, pp. 160-207, Vol. II. 
Reynolds, J.F., Virginia, R.A., Schlesinger, W.H., 1997. Defining functional types for models of desertification. In: Smith, T.M., Shugart, H.H., Woodward, F.I. (Eds.), Plant Functional Types: Their Relevance to Ecosystem Properties and Global Change. Cambridge University Press, Cambridge, pp. 195-216.

Ruimy, A., Saugier, B., Dedieu, G., 1994. Methodology for the estimation of terrestrial net primary production from remotely sensed data. J. Geophys. Res. 99, 5263-5383.

Ryan, M.G., Hunt Jr., E.R., McMurtrie, R.E., Agren, G.I., Aber, J.D., Friend, A.D., Rastetter, E.B., Pulliam, W.M., Raison, R.J., Linder, S., 1996. Comparing models of ecosystem function for temperate conifer forests. I. Model description and validation. In: Breymeyer, A.T., Hall, D.O., Mellillo, J.M., Agren, G.I. (Eds.), SCOPE 56: Global Change Effects on Coniferous Forests and Grasslands. John Wiley \& Sons, New York, pp. 313-362.

Rykiel Jr., E.J., 1996. Testing ecological models: the meaning of validation. Ecol. Modelling 90, 229-244.

Schlesinger, W.H., Reynolds, J.F., Cunningham, G.L., 1990. Biological feedbacks in global desertification. Science 247, 10431048 .

Shreve, F., 1951. Vegetation and Flora of the Sonoran Desert. Volume I. Vegetation. Carnegie Institute of Washington Publication no. 591.

Shugart, H.H., 1984. A Theory of Forest Dynamics: The Ecological Implications of Forest Succession Models. Springer-Verlag, New York.

Swartzman, G.L., Kaluzny, S.P., 1987.Ecological Simulation Primer. MacMillan Publishing, New York.

Thames, J.L., 1979. Tucson validation site report. US/IBP Desert Biome Research Memorandum 77-3. In: Final Progress Reports, Validation Studies. Utah State University, Logan, Utah.

Tiktak, A., van Grinsven, H.J.M., 1995. Review of sixteen forestsoil-atmosphere models. Ecol. Modelling 83, 35-53.
Turner, F.B., Randall, D.C., 1989. Net production by shrubs and winter annuals in Southern Nevada. J. Arid Environ. 17, 23-26.

Turner, R.M., Brown, D.E., 1994. Sonoran desertscrub. In: Brown, D.E. (Ed.), Biotic Communities: Southwestern United States and Northwestern Mexico. University of Utah Press, Salt Lake City, pp. 181-221.

Webb, W.L., Szarek, S.R., Lauenroth, W.K., Kinerson, R.S., Smith, M., 1978. Primary productivity and water use in native forest, grassland, and desert ecosystems. Ecology 59, 1239-1247.

Webb, W.L., Lauenroth, W.K., Szarek, S.R., Kinerson, R.S., 1983. Primary production and abiotic controls in forests, grasslands, and desert ecosystems in the United States. Ecology 64, 134-151.

Werk, K.S., Ehleringer, J., Forseth, I.N., Cook, C.S., 1983. Photosynthetic characteristics of Sonoran Desert winter annuals. Oecologia 59, 101-105.

Whitford, W.G., 2002. Ecology of Desert Systems. Cambridge University Press, Cambridge, UK.

Whittaker, R.H., Likens, G.E., 1973. Primary production: the biosphere and man. Human Ecol. 1, 357-369.

Whittaker, R.H., Niering, W.A., 1975. Vegetation of the Santa Catalina mountains, Arizona. V. Biomass, production, and diversity along the elevation gradient. Ecology 56, 771-790.

Wu, J., 2001. Desertification. In: Robinson, R. (Ed.), Plant Sciences. Macmillan Reference USA, New York.

Wu, J., David, J.L., 2002. A spatially explicit hierarchical approach to modeling complex ecological systems: theory and applications. Ecol. Modelling 153, 7-26.

Wu, J., Levin, S.A., 1994. A spatial patch dynamic modeling approach to pattern and process in an annual grassland. Ecol. Monographs 64, 447-464.

Wu, J., Levin, S.A., 1997. A patch-based spatial modeling approach: conceptual framework and simulation scheme. Ecol. Modelling $101,325-346$. 